\title{
Genetic Removal of Matrix Metalloproteinase 9 Rescues the Symptoms of Fragile X Syndrome in a Mouse Model
}

\author{
Harpreet Sidhu, ${ }^{1}$ Lorraine E. Dansie, ${ }^{1}$ Peter W. Hickmott, ${ }^{2}$ Douglas W. Ethell, ${ }^{3}$ and Iryna M. Ethell ${ }^{1}$ \\ ${ }^{1}$ Division of Biomedical Sciences, School of Medicine, and Neuroscience Graduate Program, and ${ }^{2}$ Department of Psychology, University of California \\ Riverside, Riverside, California 92521, and 3Department of Molecular Neurobiology, the Graduate College of Biomedical Sciences, Western University of \\ Health Sciences, Pomona, California 91766
}

\begin{abstract}
Fmr1 knock-out (ko) mice display key features of fragile X syndrome (FXS), including delayed dendritic spine maturation and FXSassociated behaviors, such as poor socialization, obsessive-compulsive behavior, and hyperactivity. Here we provide conclusive evidence that matrix metalloproteinase-9 (MMP-9) is necessary to the development of FXS-associated defects in Fmr1 ko mice. Genetic disruption of $M m p$ - 9 rescued key aspects of Fmr1 deficiency, including dendritic spine abnormalities, abnormal mGluR5-dependent LTD, as well as aberrant behaviors in open field and social novelty tests. Remarkably, MMP-9 deficiency also corrected non-neural features of Fmr1 deficiency - specifically macroorchidism - indicating that MMP-9 dysregulation contributes to FXS-associated abnormalities outside the CNS. Further, MMP-9 deficiency suppressed elevations of Akt, mammalian target of rapamycin, and eukaryotic translation initiation factor 4E phosphorylation seen in Fmr1 ko mice, which are also associated with other autistic spectrum disorders. These findings establish that MMP-9 is critical to the mechanisms responsible for neural and non-neural aspects of the FXS phenotype.
\end{abstract}

Key words: dendritic spines; extracellular matrix; fragile X syndrome; hippocampus; matrix metalloproteinase; mTOR signaling

\section{Introduction}

Fragile X syndrome (FXS) is the most common known singlegene cause of autism (Hagerman et al., 2009; Hagerman and Hagerman, 2013). FXS subjects display cognitive and behavioral impairments, as well as characteristic physical traits that include large ears, hyperextensible joints, and macroorchidism (Garber et al., 2008; Schneider et al., 2013). Expansion of a CGG triplet repeat in the untranslated 5 ' region of the fragile $\mathrm{X}$ mental retardation (FMR1) gene results in hypermethylation of the promoter and low levels of fragile X mental retardation protein (FMRP; Verkerk et al., 1991). FMRP is highly expressed in neurons, where it regulates local protein synthesis by transporting target mRNAs to dendrites and regulating mRNA translation on polyribosomes (Feng et al., 1997; Stefani et al., 2004; Dictenberg et al., 2008; Khandjian et al., 2009; Blackwell et al., 2010; Darnell et al., 2011). The dysregulation of FMRP target genes that control synaptic strength and neuronal circuit development may underlie cognitive and behavioral aspects of this disorder (Rudelli et al., 1985; Hinton et al., 1991; Fiala et al.,

\footnotetext{
Received March 21, 2014; revised May 1, 2014; accepted June 6, 2014.

Author contributions: H.S., L.E.D., D.W.E., and I.M.E. designed research; H.S., L.E.D., and I.M.E. performed research; P.W.H. contributed unpublished reagents/analytic tools; H.S., L.E.D., P.W.H., D.W.E., and I.M.E. analyzed data; H.S., L.E.D., D.W.E., and I.M.E. wrote the paper.

This work was supported by the FRAXA Research Foundation, National Institutes of Health Grant MH67121 to I.M.E., and California Institute for Regenerative Medicine Grant RNI-00538 to D.W.E. We thank Sima Mortazavi for technical assistance with mouse breeding, and members of the Ethell laboratories for helpful discussions.

The authors declare no competing financial interests.

Correspondence should be addressed to either of the following: Iryna M. Ethell, Division of Biomedical Sciences and Neuroscience Graduate Program, University of California Riverside, Riverside, California 92521, E-mail: iryna.ethell@ucr.edu; or Douglas W. Ethell, Molecular Neurobiology and the Graduate College of Biomedical Sciences, Western University of Health Sciences, Pomona, CA 91766, E-mail: dougeth64@gmail.com.

DOI:10.1523/JNEUROSCI.1162-14.2014

Copyright $\odot 2014$ the authors $\quad 0270-6474 / 14 / 349867-13 \$ 15.00 / 0$
}

1998; Weiler and Greenough, 1999; Irwin et al., 2000; Zhang et al., 2001; Hanson and Madison, 2007; Zalfa et al., 2007; Bureau et al., 2008). Fmrl knock-out (ko) mice provide an established model for FXS as they display similar dendritic spine abnormalities, cognitive deficits, impaired social behaviors, and susceptibility to audiogenic seizures as FXS subjects (Comery et al., 1997; Braun and Segal, 2000; Bassell and Gross, 2008; Bilousova et al., 2009; Cruz-Martín et al., 2010; Levenga et al., 2011).

Matrix metalloproteinase-9 (MMP-9) mRNA was recently identified as an FMRP target, and its translation is locally regulated by FMRP in the dendrites following neuronal stimulation (Dziembowska and Wlodarczyk, 2012; Janusz et al., 2013). We previously reported higher MMP-9 activity in Fmr1 ko mouse brains, suggesting that MMP-9 dysregulation may contribute to FXS-associated deficits (Bilousova et al., 2006, 2009). Further, minocycline rescues dendritic spine defects in Fmrl ko neurons (Bilousova et al., 2009), and attenuates behavioral and cognitive abnormalities in Fmrl ko mice (Rotschafer et al., 2012; Dansie et al., 2013). Moreover, clinical trials have reported that minocycline has beneficial effects on cognition and aberrant social behaviors in FXS subjects (Paribello et al., 2010; Dziembowska et al., 2013; Leigh et al., 2013; Schneider et al., 2013). However, it remains unclear whether the benefits of minocycline are due to its inhibitory effects on MMP-9 or its antibiotic properties.

To evaluate the role of MMP-9 in behavioral and morphological deficits associated with loss of FMRP, we produced double ko (dbl ko) mice that are deficient for both Mmp-9 and Fmrl. Our findings establish that MMP-9 is necessary for the development of anatomical, behavioral, and biochemical abnormalities associated with the FXS phenotype. The dbl ko mice exhibited normal dendritic spine maturation, normal mGluR5-dependent long- 
term depression (LTD), and performed similarly to wild-type (wt) mice in open field and social novelty tests. Remarkably, MMP-9 deficiency also prevented macroorchidism in dbl ko mice, suggesting that MMP-9 dysregulation also contributes to FXS-associated abnormalities outside the CNS.

\section{Materials and Methods}

Ethics statement. All animal care protocols and procedures were approved by the University of California Riverside Animal Care and Use Program, which is accredited by Association for Assessment and Accreditation of Laboratory Animal Care International (AAALAC), and animal welfare assurance number A3439-01 is on file with the Office of Laboratory Animal Welfare.

Mice. The FVB.Cg-Mmp- $9^{t m 1 T v u} / \mathrm{J}$ and FVB.129P2-Fmr1 ${ }^{\text {tm1Cgr }} / \mathrm{J}$ (Fmr1 ko) and FVB.129P2-Pde6b ${ }^{+} \mathrm{Tyr}^{\mathrm{c}-\mathrm{ch}} / \mathrm{Ant}$ J controls (wt) were obtained from The Jackson Laboratory. The FVB.Cg-Mmp- $9^{t m 1 T v u} / \mathrm{J}$ mice were backcrossed, in-house, with the Fmrl ko and wt mice to generate Fmr1/Mmp-9 dbl ko mice and Mmp-9 ko mice, respectively. These mice do not suffer from retinal degeneration due to restoration of the pde6b allele and do not develop blindness, making them a suitable model for behavioral analysis. All genotypes were confirmed by PCR analysis of genomic DNA isolated from mouse tails. Mice were maintained in an AAALAC-accredited facility under $12 \mathrm{~h}$ light/dark cycles and were fed standard mouse chow. All mouse studies were performed within $\mathrm{Na}-$ tional Institutes of Health and Institutional Animal Care and Use Committee guidelines.

Hippocampal neuron cultures. Cultures of hippocampal neurons were prepared from embryonic day 15 (E15) or E16 pups. Briefly, hippocampal cells were treated with papain $(0.5 \mathrm{mg} / \mathrm{ml})$ and DNase $(0.6 \mu \mathrm{g} / \mathrm{ml})$ for $20 \mathrm{~min}$ at $37^{\circ} \mathrm{C}$, mechanically dissociated, and then plated on glass coverslips that had been precoated with poly-DL-ornithine $(0.5 \mathrm{mg} / \mathrm{ml}$ in borate buffer) and laminin ( $5 \mu \mathrm{g} / \mathrm{ml}$ in PBS). The hippocampal cells were cultured in Neurobasal medium with $25 \mu \mathrm{M}$ glutamine, $1 \%$ penicillinstreptomycin, and B27 supplement (Invitrogen), under $5 \% \mathrm{CO}_{2} / 10 \% \mathrm{O}_{2}$ atmosphere at $37^{\circ} \mathrm{C}$. Hippocampal neurons were transfected with pEGFP plasmid at $10 \mathrm{~d}$ in vitro (DIV) using a calcium phosphate method, as previously described (Shi and Ethell, 2006).

Human brain tissue samples and ELISA. Brain tissue samples of human neocortex and hippocampus were obtained from Dr. Cara Westmark from the University of Wisconsin (Madison, WI) with permission from the National Institute of Child Health and Human Development Brain and Tissue Bank for Developmental Disorders at the University of Maryland (Baltimore, MD).

Brain tissue samples were homogenized in lysis buffer containing 10 mм Tris- $\mathrm{HCl}, \mathrm{pH} 7.4,150 \mathrm{~mm} \mathrm{NaCl}, 1 \mathrm{~mm}$ EDTA, and $0.5 \%$ Triton X-100. Total activity of MMP-9 was measured in brain tissue lysates following the protocol for lower endogenous levels using the MMP-9 Biotrak Activity Assay (RPN2634, GE Healthcare). Total levels of tissue inhibitor of metalloproteinase-1 (TIMP-1) were measured in brain tissue lysates following the protocol for the TIMP-1 Human Biotrak ELISA System (RPN2611, GE Healthcare). Original brain tissue lysates were diluted and measured for total protein concentrations following the protocol for the BCA colorimetric protein assay (catalog \#23235, Pierce). Appropriate dilutions were determined for every trial by running a dilution curve on two randomly selected prepared samples. Data processing was performed following the instructions provided with the protocols. Each assay was performed at least two times, and each sample was analyzed in duplicate. Statistical analysis was performed using Student's $t$ test for comparisons between two groups (control and FXS).

Quantitative RT-PCR. Hippocampal and cortical tissues were dissected from mice at postnatal day (P) 8, P14, and P21 ( $n=3-5$ mice per group per time point). Total RNA from each tissue sample was prepared using Trizol (Life Technologies) according to the manufacturer's instructions, and cDNA was transcribed using SuperScript VILO cDNA Synthesis Kit (Life Technologies). Each reaction mixture contained $1 \times$ Power SYBR Green PCR Master Mix (Life Technologies), and all the reactions were run in triplicate. The PCR amplification protocol was as follows: initial DNA polymerase activation at $95^{\circ} \mathrm{C}$ for $10 \mathrm{~min}$, followed by 40 cycles with denaturation at $95^{\circ} \mathrm{C}$ for $15 \mathrm{~s}$, and annealing plus extension at $60^{\circ} \mathrm{C}$ for $1 \mathrm{~min}$. Amplification was performed in a StepOne Real Time PCR System (96-well format; Life Technologies) and analyzed by normalizing the expression of each gene to GAPDH within each tissue sample. Statistical analysis was performed using two-way ANOVA followed by pair-by-pair comparisons using the Bonferroni post hoc test.

The following primers were used: Mmp2_F-GGACCCCGGTTTC CCTAA; Mmp2_R-CAGGTTATCAGGGATGGCATTC; Mmp3_F-CC CCTGATGTCCTCGTGGTA; Mmp3_R-GCACATTGGTGATGTCTC AGGTT; Mmp7_F-CCTAGGCGGAGATGCTCACT; Mmp7_R-CCT GCGTCCTCACCATCAG; Mmp8_F-CACGCACCCTATGAGGACAA; Mmp8_R-GCAGGACACGTGGGATGAGT; Mmp9_F-AGTGGGACC ATCATAACATCACAT; Mmp9_R-TCTCGCGGCAAGTCTTCAG; Mmp12_F-TGAGGCAGGAGCTCATGGA; Mmp12_R-GGCTTGATT CCTGGGAAGTG; Mmp21_F-GCACCATCACCAGCTCCTTT; Mmp21_RCGTAAGCCGCGTCCACAT; Mmp24_F-TCACCGGTGTGTTGGAT CAG; Mmp24_R-GGACGCCACATCGAGGTTT, Gapdh_F-CCACAG TCCATGCCATCAC; Gapdh_R-CACCACCCTGTTGCTGTAGCC.

Immunoblotting. The hippocampus was removed from each mouse ( $n=4$ mice per group), cooled in PBS, and homogenized in cold RIPA buffer (50 mu Tris-HCl, pH 7.4, 150 mm NaCl, 1 mm EDTA, pH 8.0, 1\% Triton X-100, 0.1\% SDS, and 0.5\% 21-hydroxyprogesterone) containing protease inhibitor cocktail (Sigma) and $0.5 \mathrm{~mm}$ sodium pervanadate. The samples were rotated at $4^{\circ} \mathrm{C}$ for at least $1 \mathrm{~h}$ to allow for complete cell lysis and then cleared by centrifugation at $13,200 \mathrm{rpm}$ for $15 \mathrm{~min}$ at $4^{\circ} \mathrm{C}$. Supernatants were isolated and boiled in reducing sample buffer (Laemmli $2 \times$ concentrate, S3401, Sigma), and separated on $8-16 \%$ Trisglycine SDS-PAGE precast gels (EC6045BOX, Life Technologies). Proteins were transferred onto Protran BA 85 Nitrocellulose membrane (GE Healthcare) and blocked for $1 \mathrm{~h}$ at room temperature in 5\% skim milk (catalog \#170-6404, Bio-Rad). Primary antibody incubations were performed overnight at $4^{\circ} \mathrm{C}$ with antibodies diluted in TBS/0.1\% Tween$20 / 5 \%$ BSA. The following primary antibodies were used: rabbit $\alpha$ - eukaryotic translation initiation factor 4E (eIF4E; C46H6; catalog \#2067, RRID:AB_2097675); rabbit $\alpha$-phospho-eIF4E (Ser209; catalog \#9741, RRID:AB_331677); rabbit $\alpha$-mammalian target of rapamycin (mTOR; 7C10; catalog \#2983, RRID:AB_2105622); rabbit $\alpha$-phospho-mTOR (Ser2481; catalog \#2974, RRID:AB_2231885); rabbit $\alpha$-Akt (catalog \#9272; RRID:AB_10699016); rabbit $\alpha$-phospho-Akt (Ser473; catalog \#9271, 329825); rabbit $\alpha$-p44/p42 mitogen-activated protein kinase (MAPK) (catalog \#9102; RRID:AB_10695746); rabbit $\alpha$-phospho-p44/ p42 MAPK (Thr202/Tyr204; catalog \#9101, RRID:AB_331646); rabbit a-phospho-focal adhesion kinase (p-FAK; catalog \#44-624G, Invitrogen, RRID:AB_1500097); rabbit a-FAK (catalog \#06-543, Millipore, RRID: AB_310162); rabbit a-Integrin $\beta 3$ (catalog \# AB1932, Millipore, RRID: AB_2128910); rabbit a-eIF4E binding protein (4E-BP; 53H11; catalog \#9644P, RRID: AB_2097841); rabbit a-p-4E-BP (Ser65; catalog \#9451P, RRID: AB_330947) and mouse $\alpha$-GAPDH at 1:1000 (catalog \#10RG1099, Fitzgerald). All primary antibodies were from Cell Signaling Technology and used at a dilution of 1:1000, unless stated otherwise. Blots were washed $3 \times 10 \mathrm{~min}$ with TBS/0.1\% Tween-20 and incubated with the appropriate HRP-conjugated secondary antibodies for $1 \mathrm{~h}$ at room temperature in a TBS $/ 0.1 \%$ Tween-20/5\% BSA solution. The secondary antibodies used were $\alpha$-rabbit-HRP at 1:5000 and $\alpha$-mouse-HRP at 1:5000 (GE Healthcare). After secondary antibody incubations, blots were washed $3 \times 10 \mathrm{~min}$ in TBS/0.1\% Tween-20 and developed with ECL Detection reagent (catalog \#80196, Thermo Scientific). For reprobing, membrane blots were washed in stripping buffer (2\% SDS, $100 \mathrm{~mm}$ $\beta$-mercaptoethanol, $50 \mathrm{~mm}$ Tris- $\mathrm{HCl}, \mathrm{pH} 6.8$ ) for $30 \mathrm{~min}$ at $56^{\circ} \mathrm{C}$, then rinsed repeatedly with $\mathrm{TBS} / 0.1 \%$ Tween-20, finally blocked with $5 \%$ skim milk, and then reprobed. Developed films were then scanned, and protein levels were quantified by comparing band density values obtained using ImageJ. Two samples per group were run per blot, and precision/tolerance $(\mathrm{P} / \mathrm{T})$ ratios for different samples were normalized to averaged $\mathrm{P} / \mathrm{T}$ ratios of wt samples. Statistical analysis was performed using two-way ANOVA followed by post hoc pair-by-pair comparisons with Fisher's least significant difference (LSD) method.

APMA-mediated activation of MMP-9. Recombinant mouse MMP-9 (catalog \#CC069, Millipore Bioscience Research Reagents; catalog \#909- 
MM-010, R\&D Systems) was activated with $1 \mathrm{~mm}$ APMA (catalog \#A9563, Sigma) in $50 \mathrm{~mm}$ Tris-HCl, pH 7.5, containing $150 \mathrm{~mm} \mathrm{NaCl}, 5$ $\mathrm{mm} \mathrm{CaCl} 2,2.5 \mathrm{~mm} \mathrm{ZnCl} 2$, and $0.05 \%$ Brij-35 (activation buffer) at $37^{\circ} \mathrm{C}$ for $2 \mathrm{~h}$. Activated MMP-9 was used to treat hippocampal cultures at a concentration of $100 \mathrm{ng} / \mathrm{ml}$ for 5,15 , and 30 min under $5 \% \mathrm{CO}_{2} / 10 \% \mathrm{O}_{2}$ atmosphere at $37^{\circ} \mathrm{C}$.

Immunoprecipitation. The 14 DIV treated and untreated hippocampal neurons were lysed in ice-cold TBS ( $25 \mathrm{~mm}$ Tris, pH 7.4; $0.15 \mathrm{~mm} \mathrm{NaCl}$ ) containing $1 \%$ Triton X-100, 5 mm EDTA, $0.5 \mathrm{~mm}$ sodium pervanadate, and protease inhibitor mixture (catalog \#P8340, Sigma). Cell lysates were cleared by centrifugation at $12,000 \times g$. Supernatant was incubated with $2 \mu \mathrm{l}$ of rabbit anti-FAK antibody (catalog \#06-543, Millipore) and $20 \mu \mathrm{l}$ of protein A-Agarose beads (catalog \#P1406, Sigma) for $4 \mathrm{~h}$ at $4^{\circ} \mathrm{C}$. Bound materials were eluted with SDS-PAGE sample buffer and analyzed via Western immunoblotting.

Gelatin zymography. Gelatin gel zymography was performed as previously described (Zhang and Gottschall, 1997; Manabe et al., 2005) with minor modifications. Briefly, hippocampal tissues isolated from agematched male mice ( $n=4$ mice per group) were resuspended in $50 \mathrm{~mm}$ Tris- $\mathrm{HCl}$ (pH 7.6) buffer containing $150 \mathrm{~mm} \mathrm{NaCl}, 5 \mathrm{~mm} \mathrm{CaCl}, 0.05 \%$ Brij35, 0.02\% $\mathrm{Na}_{3} \mathrm{~N}, 1 \%$ Triton X-100, $100 \mu \mathrm{M}$ PMSF, and protease inhibitor cocktail (Sigma). The gelatinases, MMP-2 and MMP-9, were pulled down with gelatin agarose beads (catalog \#G5384, Sigma) and separated on nonreducing SDS-PAGE gels containing $0.1 \%$ gelatin (Invitrogen). Following separation, gels were soaked in $1 \times$ renaturing buffer (catalog \#LC2670, Invitrogen) to remove all traces of SDS and allow the MMPs to refold, thus regaining most of their enzymatic activity. Following renaturation, gels were incubated in $1 \times$ developing buffer (catalog \#LC2671, Invitrogen) for $96 \mathrm{~h}$, which allowed the gelatinases (MMP-2 and MMP-9) to degrade gelatin in the gel. Gels were then stained with Coomassie Blue overnight to uniformly stain the gels, after which destaining revealed areas of MMP activity as unstained bands. Levels of MMP-2 and MMP-9 proteins were quantified by densitometry. Statistical analysis was performed using Student's $t$ test for comparisons between two groups and two-way ANOVA for multiple comparisons when appropriate.

Immunocytochemistry and image analysis. Cultured hippocampal neurons were fixed in $2 \%$ paraformaldehyde (PFA) in PBS, permeabilized in $0.01 \%$ Triton X-100 in PBS, and then blocked in PBS containing 5\% normal goat serum and $1 \%$ BSA. Dendritic spines and filopodia were visualized by GFP fluorescence. Presynaptic boutons were labeled by immunostaining for the presynaptic vesicle marker synapsin using rabbit anti-synapsin I antibody $(10 \mu \mathrm{g} / \mathrm{ml}$; AB1543P, Millipore, RRID: AB_90757), the excitatory synapse marker vesicular glutamate transporter 1 (vGLUT1) using rabbit anti-vGLUT1 ( $1 \mu \mathrm{g} / 4 \mu \mathrm{l}$; catalog \#482400, Invitrogen), and the inhibitory synapse marker glutamate decarboxylase 65 (GAD65) and using mouse anti-GAD65 (10 $\mu \mathrm{g} / \mathrm{ml}$; cata$\log$ \#559931, BD Pharmingen, RRID:AB_397380). Postsynaptic sites were identified by immunostaining against PSD-95 using rabbit antiPSD95 (catalog \#CP35, Calbiochem, RRID:AB_2092542). The secondary antibodies used were Alexa Fluor 594-conjugated goat anti-mouse IgG (4 $\mu \mathrm{g} / \mathrm{ml}$; catalog \#A11005, Invitrogen, RRID:AB_141372), Alexa Fluor 647-conjugated donkey anti-rabbit IgG (4 $\mu \mathrm{g} / \mathrm{ml}$; catalog \#A31573, Invitrogen, RRID:AB_162544), or Alexa Fluor 488-conjugated donkey anti-rabbit IgG ( $4 \mu \mathrm{g} / \mathrm{ml}$; catalog \#A21206, Invitrogen, RRID: AB_141708). Fluorescent images were taken using a confocal laserscanning microscope (model LSM 510, Carl Zeiss MicroImaging) with $63 \times$ water Fluor objective. Image analysis was performed using ImageJ software (RRID: nif-0000-30467) as previously described (Bilousova et al., 2006). Briefly, experimental and control samples were encoded for blind analysis. In each experiment two to three coverslips were analyzed for each condition. At least 10 GFP-transfected spiny pyramidal neurons were randomly imaged in each group. Secondary dendrites were selected for morphometric analysis of dendritic spines using the LSM Image Browser (Carl Zeiss). Densities of dendritic protrusions were determined as the number of protrusions per $10 \mu \mathrm{m}$ of dendrite. Lengths of dendritic protrusions were measured from protrusion tip to dendritic shaft. Dendritic spines were identified as dendritic protrusions connected with synapsin-positive presynaptic terminals and were grouped into the fol- lowing three categories according to their morphology: (1) thin (long, thin protrusions with small heads); (2) mushroom (short protrusions with large heads and thin necks); and (3) stubby (short protrusions with thick necks and no heads). Dendritic protrusions lacking adjacent presynaptic boutons were considered to be filopodia. Each experiment was performed at least three times. Statistical analysis was performed using two-way ANOVA followed by post hoc pair-by-pair comparisons with the Bonferroni correction for multiple comparisons.

Immunohistochemistry and spine analysis. Age-matched male mice at ages P8, P14, P21, and P60 (adult) were anesthetized with isoflurane and perfused with cold PBS followed by $4 \%$ PFA. Brains were extracted and postfixed in $4 \%$ PFA at $4^{\circ} \mathrm{C}$ for $2-4 \mathrm{~h}$ before being sectioned coronally into $100 \mu \mathrm{m}$ slices on a vibratome. Sections were then biolistically labeled with $1,1^{\prime}$-dioctadecyl-3,3,3',3'-tetramethylindocarbocyanine perchlorate (DiI) using a gene gun and incubated in PBS for $3 \mathrm{~d}$ at $4^{\circ} \mathrm{C}$ before being mounted onto slides in PBS and sealed with Cytoseal 60 (Fisher Scientific). Pyramidal neurons in CA1 were imaged by confocal microscopy (model LSM 510, Carl Zeiss MicroImaging) using a series of highresolution optical sections $(1024 \times 1024$-pixel format $)$ that were captured for each neuron with a $63 \times$ water-immersion objective $(1.2$ numerical aperture), with $1 \times$ zoom at $1 \mu \mathrm{m}$ step intervals ( $z$-stack). All images were acquired under identical conditions. Each $z$-stack was collapsed into a single image by projection (LSM Image Browser, Zeiss), converted to a tiff file, encoded for blind analysis, and analyzed using ImageJ. The "line tool" was used to measure dendritic spine lengths by drawing over the lengths of dendrites or the lengths of spines from the base of the dendrite to the base of the spine head if any or the tip of the spine in the case of filopodial spines. The "freehand selection" tool was used to draw regions of interest around the spine heads, and those areas were taken as a measure of spine head area. Sections analyzed for puncta number were labeled by immunostaining for synapsin I, vGlut1, GAD65, and/or PSD-95, as described above; imaged using confocal microscopy in $z$-stacks; each image in the series was threshold adjusted to identical levels; and finally puncta were analyzed using ImageJ. At least three animals were analyzed per group, and sections from at least 20 neurons were imaged per animal. Statistical analysis was performed using two-way ANOVA followed by post hoc pair-by-pair comparisons with the Bonferroni correction for multiple comparisons.

Electrophysiology. Mice at P21-P28 (six animals, 10-17 slices per group) were anesthetized by isoflurane inhalation. Brains were removed from the skull, and immediately immersed in chilled cutting solution containing $110 \mathrm{~mm}$ sucrose, $60 \mathrm{~mm} \mathrm{NaCl}, 28 \mathrm{~mm} \mathrm{NaHCO}, 1.25 \mathrm{~mm}$ $\mathrm{NaH}_{2} \mathrm{PO}_{4}, 3 \mathrm{~mm} \mathrm{KCl}, 7 \mathrm{~mm} \mathrm{MgSO}, 0.5 \mathrm{~mm} \mathrm{CaCl}_{2}, 5 \mathrm{~mm}$ glucose, and 0.6 $\mathrm{mm}$ ascorbic acid, bubbled with $95 \% \mathrm{O}_{2} / 5 \% \mathrm{CO}_{2}$. Transverse hippocampal slices $(400 \mu \mathrm{m}$ thick) were prepared using a Vibratome (model VT1200S, Leica) and were allowed to recover in the cutting solution for $30 \mathrm{~min}$ at room temperature followed by an additional hour in artificial CSF (ACSF) containing $124 \mathrm{~mm} \mathrm{NaCl}, 25 \mathrm{~mm} \mathrm{NaHCO}_{3}, 1 \mathrm{~mm} \mathrm{NaHPO}_{4}$, $4.4 \mathrm{~mm} \mathrm{KCl}, 1.2 \mathrm{~mm} \mathrm{MgSO}_{4}, 2 \mathrm{~mm} \mathrm{CaCl}_{2}$, and $10 \mathrm{~mm}$ glucose with constant bubbling of $95 \% \mathrm{O}_{2} / 5 \% \mathrm{CO}_{2}$ gas. Extracellular field EPSPs (fEPSPs) were recorded in the stratum radiatum of CA1 with glass electrodes $(5 \mathrm{M} \Omega$ ) filled with ACSF. Stimuli were delivered to the commissural/Schaffer collateral afferents with a bipolar electrode positioned parallel to the recording electrode and $200 \mu \mathrm{m}$ from it. For mGluR5 LTD, after $10 \mathrm{~min}$ of stable baseline recording, $100 \mu \mathrm{M}$ (S)-3,5dihydroxyphenylglycine (DHPG) was washed into the slice for $10 \mathrm{~min}$ before being replaced with ACSF, and LTD was sampled at $30 \mathrm{~s}$ intervals for $60 \mathrm{~min}$ after DHPG treatment. Initial fEPSP slopes were calculated as $20-80 \%$ of the field recordings obtained, and depression was calculated by dividing the average slope of postinduction responses by the average slope of preinduction baseline responses. Statistical analysis was performed using two-way ANOVA followed by post hoc pair-by-pair comparisons with the Bonferroni correction.

Open field test. Anxiety was tested in $\mathrm{P} 60$ mice (12-17 mice per group) by quantifying their tendency to travel to the center of an open field (Yan et al., 2004; Yan et al., 2005). A $72 \times 72 \mathrm{~cm}$ open field arena with $50-\mathrm{cm}-$ high walls was constructed from opaque acrylic sheets with a clear acrylic sheet for the bottom with a grid placed underneath it for scoring purposes. The open field arena was placed in a brightly lit room, and one 


\section{A Gelatin zymography: adult mouse hippocampus}

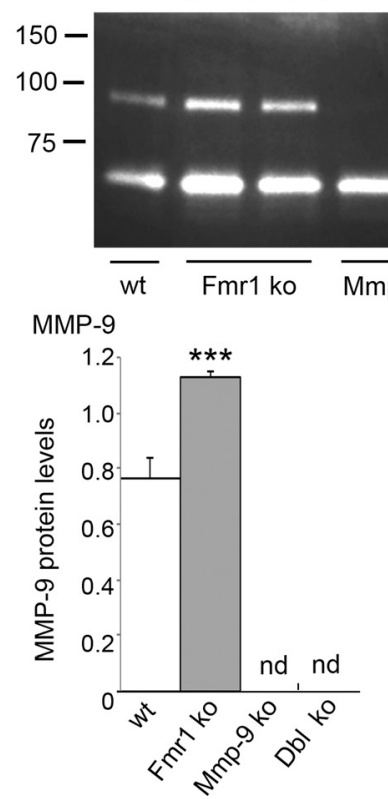

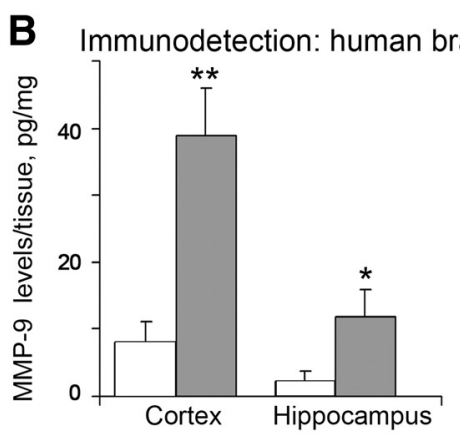
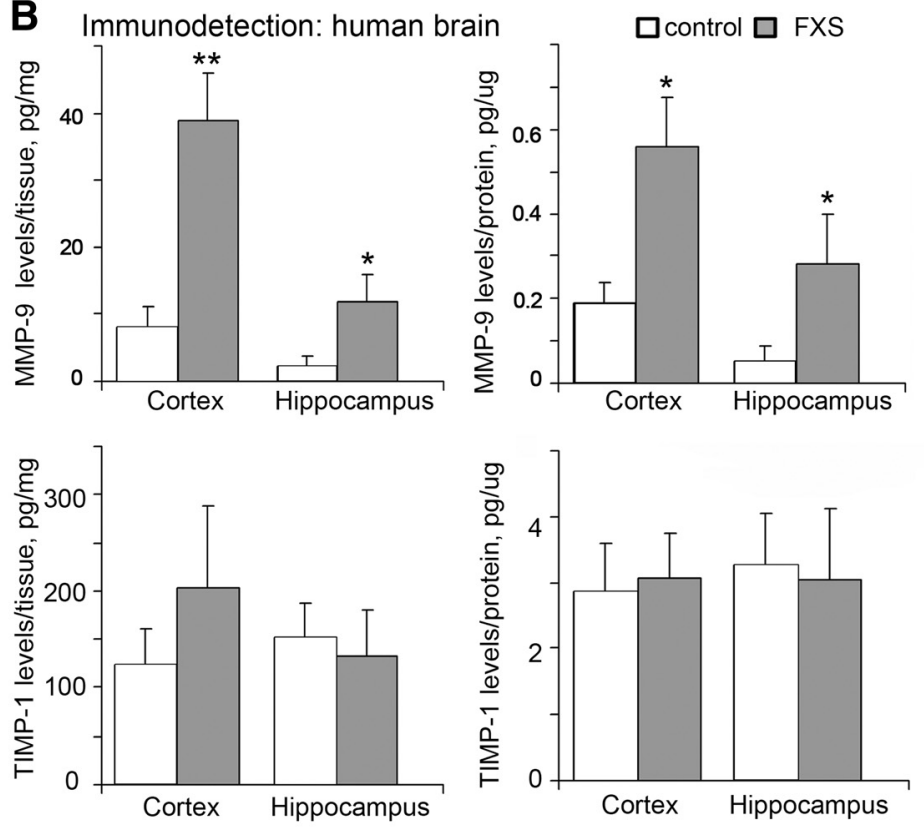

\section{Real time PCR: mouse hippocampus}
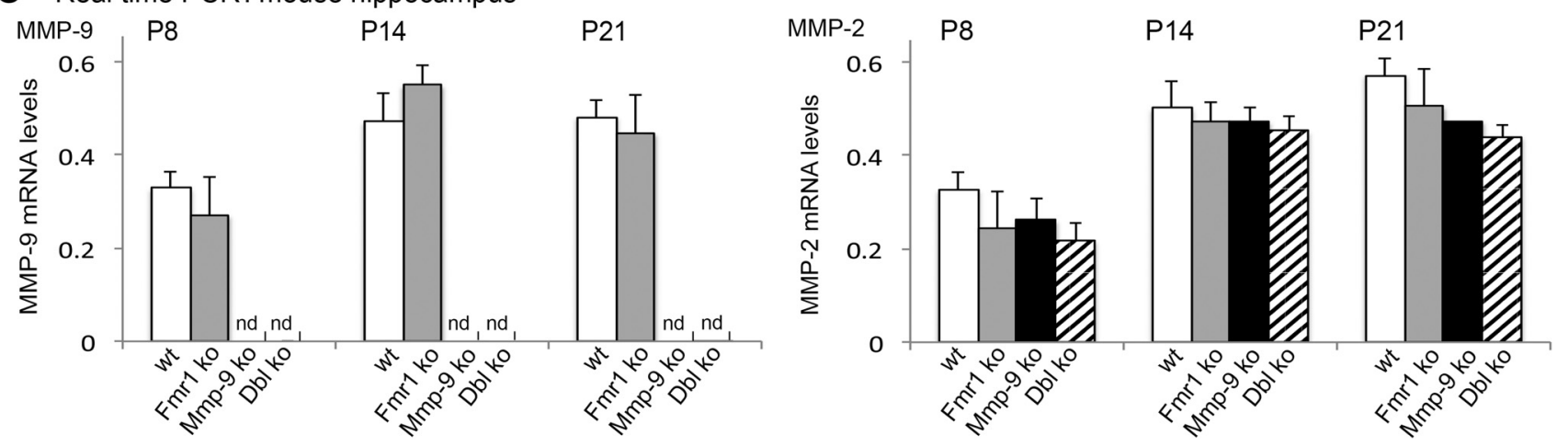

Figure 1. Gelatinase levels are upregulated in the hippocampi of Fmr 1 ko mice and brain samples of FXS human subjects. $A$, Detection of MMP- 9 and MMP-2 levels in the hippocampi of wt, Fmr 1 ko, Mmp-9 ko, and dbl ko adult mice. Levels of the gelatinases were detected by gelatin zymography, quantified by densitometry, and normalized to total protein concentration. Bar graphs show average MMP-9 and MMP-2 levels, and the error bars indicate SEM ( $n=4$ mice per group). Statistical analysis was performed using Student's $t$ test for MMP-9 and two-way AN0VA for MMP-2: $p<$ $0.05,{ }^{* * *} p<0.001$. B , Total levels of MMP-9 and TIMP-1 in the hippocampal and cortical tissue samples of FXS subjects and age-matched controls were quantified by MMP Activity Assays and TIMP-1 ELISA. The bar graphs indicate average values normalized to total tissue weight and total protein levels. Error bars indicate SEM ( $n=4$ human subjects per group). Statistical analysis was performed using Student's $t$ test: * $\left.p<0.05,{ }^{* *} p<0.01\right)$. C, Mmp-9 and Mmp-2 mRNA levels were detected by quantitative real-time PCR in P7, P14, and P21 hippocampi of wt, Fmr 1 k0, Mmp-9 ko, and dbl ko mice. The bar graphs represent the Mmp mRNA levels normalized to Gapdh levels for each sample. Error bars indicate SEM ( $n=3-5$ mice per group). Statistical analysis was performed using two-way ANOVA followed by Bonferroni multiple-comparison post-test: nd, Not detected.

mouse at a time was placed in a corner of the open field and allowed to explore for $20 \mathrm{~min}$ while being recorded with digital video from above. The tester left the room during testing. The floor was cleaned with $2-3 \%$ acetic acid, $70 \%$ ethanol, and water between tests to eliminate odor trails. The mice were tested between the hours of 8:00 A.M. and 1:00 P.M., and had not undergone any other behavioral tests before this testing paradigm. Locomotor activity was scored as described previously with some modifications (Brown et al., 1999; Yan et al., 2005) using TopScan Lite software (CleverSys Inc). The arena was subdivided into a $4 \times 4$ grid of squares with a separate square of equal size in the middle. A line $4 \mathrm{~cm}$ from each wall was added to measure thigmotaxis. Total horizontal and vertical line crosses, average velocity, total entries into large and small center squares, time spent in the large and small center squares, velocity within the large and small center squares, and time spent along the walls (thigmotaxis) were scored by the program, and a tendency to travel to the center (total number of entries into large and small center squares) was used as an indicator of anxiety. Average velocity and total line crosses were measured to score locomotor activity. The analysis was performed in $5 \mathrm{~min}$ intervals for the total $10 \mathrm{~min}$ exploration duration. Assessments of the digital recordings were performed by blinded observers using TopScan Lite software (CleverSys Inc). Statistical analysis was performed using two-way ANOVA followed by post hoc pair-by-pair comparisons with the Newman-Keuls correction for multiple comparisons.

Social novelty test. Sociability and social memory were studied using a three-chamber paradigm as described previously (Kaidanovich-Beilin et al., 2011). Briefly, a rectangular box contained three adjacent chambers $19 \times 45 \mathrm{~cm}$ each, with 30 -cm-high walls and a bottom constructed from clear Plexiglas. The three chambers were separated by dividing walls made from clear Plexiglas with openings between the middle chamber and each side chamber. Removable doors over these openings permitted chamber isolation or free access to all chambers. All testing was performed in a brightly lit room (650 lux), between 9:00 A.M. and 6:00 P.M. Before testing, mice were housed five mice per cage in a room with a $12 \mathrm{~h}$ light/dark cycle with ad libitum access to food and water. The cages were transferred to the behavioral room $30 \mathrm{~min}$ before the first trial began. The test mouse was placed in the central chamber with no access to the left and right chambers, and was allowed to habituate to the test chamber for $5 \mathrm{~min}$ before testing began. In session 1, another mouse [stranger 1 (S1)] 
A Dendritic spine analysis

wt

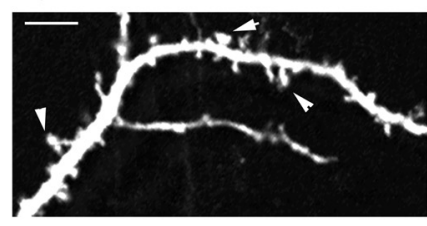

B

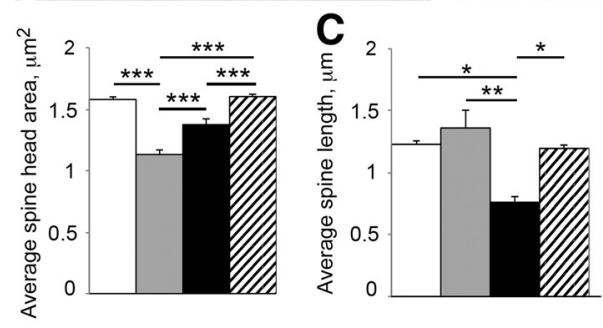

Fmr1 ko
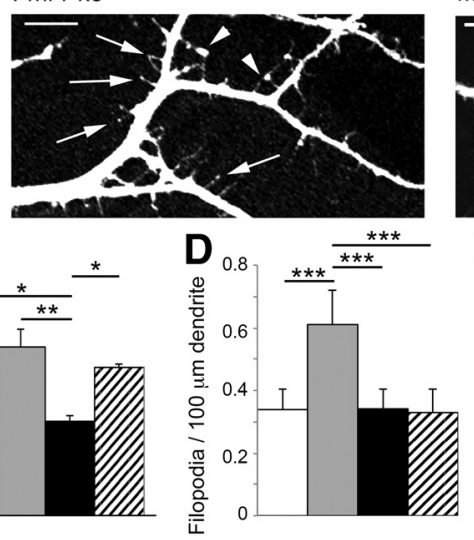

Mmp-9 ko

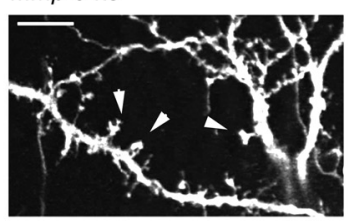

$\mathbf{E}$
14 div hippocampal neurons in vitro Dbl ko
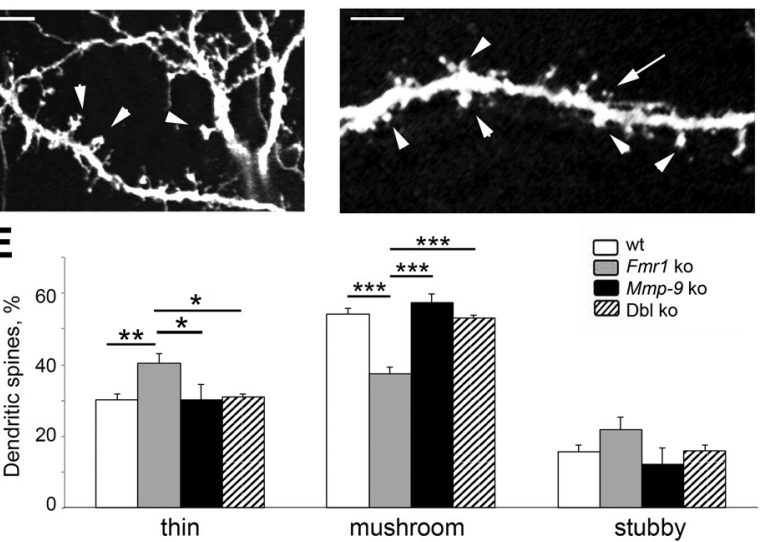

F Immunodetection of pre-synaptic boutons
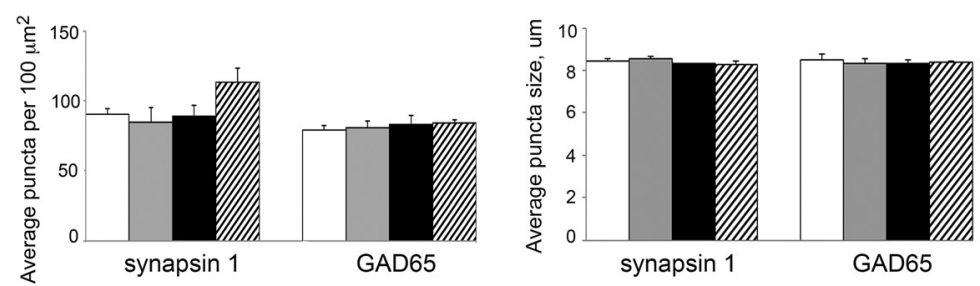

Figure 2. Genetic deletion of Mmp-9 promotes the formation of mature dendritic spines in the Fmr 1 ko hippocampal neurons in vitro. A, Confocal images showing the dendrites of 14 DIV hippocampal neurons from wt, Fmr1 ko, Mmp-9 ko, and dbl ko mice. Dendritic morphology was visualized by GFP fluorescence. Arrowheads denote mature mushroom spines, while the arrows denote immature thin spines. Scale bars, $10 \mu \mathrm{m} . \boldsymbol{B}-\boldsymbol{E}$, Quantitative analysis of spine head areas $(\boldsymbol{B})$; spine lengths $(\boldsymbol{C})$; filopodia density $(\boldsymbol{D})$; and the proportion of thin, mushroom, and stubby spines in wt, $F m r 1$ ko, Mmp-9 ko, and dbl ko hippocampal neurons (E). All bar graphs show average values, and error bars indicate SEM ( $n=400-700$ dendritic spines from 8 to 12 neurons per group). Statistical analysis was performed using two-way ANOVA followed by Bonferroni multiple-comparison post-test: ${ }^{*} p<0.05,{ }^{* *} p<0.01,{ }^{* * *} p<0.001$. $F$, Presynaptic boutons were identified by immunostaining against Synapsin 1 and GAD65. Average density of puncta and size were quantified. Bar graphs represent average values, and the error bars indicate SEM ( $n=8-12$ neurons per group). Statistical analysis was performed using two-way ANOVA followed by Bonferroni multiple-comparison post-test. No significant differences were found between the groups.

was placed in a wire cup-like container in one of the side chambers. The opposite side had an empty cup of the same design. The doors between the chambers were removed, and the test mouse was allowed to explore all three chambers freely for $10 \mathrm{~min}$, while being video recorded from above. The following parameters were monitored: the duration and number of direct contacts between the test mouse and the stranger mouse or the empty cup; the duration and number of other behaviors exhibited by the subject mouse, such as self-grooming, walking, and freezing; as well as the number and duration of entries into each chamber. In session 2, a new mouse (stranger 2) was placed in the empty wire cup in the second side chamber. Stranger 1, the now familiar mouse, remained in the first side chamber. The test mouse was allowed to freely explore all three chambers for another $10 \mathrm{~min}$, and the same parameters were monitored. The placement of stranger 1 in the left or right side of the chamber was randomly altered between trials. Each testing session lasted $10 \mathrm{~min}$, and the session was recorded digitally from above, with the tester leaving the room for the duration of the trial. The floor of the chamber was cleaned with 2-3\% acetic acid, $70 \%$ ethanol, and water between tests to eliminate odor trails. Assessments of the digital recordings were performed by blinded observers using TopScan Lite software (CleverSys Inc). Statistical analysis was performed using two-way ANOVA followed by post hoc pair-by-pair comparisons with the Bonferroni correction.

Testes measurements. Testes were dissected from male P30 mice into a $1 \times$ PBS solution. Six mice were used for each genotype, yielding a total of 12 testes per group. The weight of each testis was measured to three decimal places using a scale. The volume was calculated based on the amount of water the testes displaced from an Eppendorf tube filled with $1 \mathrm{ml}$ of PBS. Finally, pictures of testes were analyzed with Image to calculate the area of each testis. Each measurement was repeated at least three times for every individual testis. Statistical analysis was performed using two-way ANOVA followed by post hoc pair-by-pair comparisons with the Bonferroni correction for multiple comparisons.

\section{Results}

MMP-9 levels are higher in the hippocampus of FXS human subjects and Fmr1 ko mice

We previously showed high levels of MMP-9 in the hippocampus of Fmrl ko mice at P8 and P14 (Bilousova et al., 2009), and here we found that this upregulation of MMP-9 levels is maintained in the adult Fmrl ko hippocampus (Fig. 1A). Gelatin zymography revealed a significant increase in protein levels of both gelatinases, MMP-9 and MMP-2, in the adult hippocampus of Fmrl ko mice, compared with wt mice ( $p=0.0001$ and $p=0.0176$; Fig. $1 A$ ). MMP-9 protein levels were also significantly higher in postmortem brain samples from FXS human subjects compared with control subjects $(p=0.0259, n=4$; Fig. $1 B)$, although levels of TIMP-1 were not significantly different (Fig. $1 B$ ). While protein levels of MMP-9 and MMP-2 were higher in the brains of FXS subjects and Fmrl ko mice, mRNA levels for these gelatinases were not elevated in hippocampi of Fmrl ko mice (Fig. 1C), suggesting post-transcriptional dysregulation of MMP-9 and MMP-2 in the hippocampi of Fmrl ko mice.

Loss of MMP-9 corrects spine maturation in Fmr1/Mmp-9 ko hippocampal neurons in vitro

We investigated whether high MMP-9 levels contribute to the abnormal development of dendritic spines in Fmr1 ko mice by generating dbl ko mice that are deficient for both Fmrl and MMP-9. As we previously reported (Bilousova et al., 2009), Fmr1 ko neurons develop a higher proportion of immature spines with small heads and more filopodia in vitro $(p<0.0001$; Fig. $2 B, D)$. We found a significant enlargement of spine heads, a decrease in 
A mouse CA1 hippocampal neurons in vivo

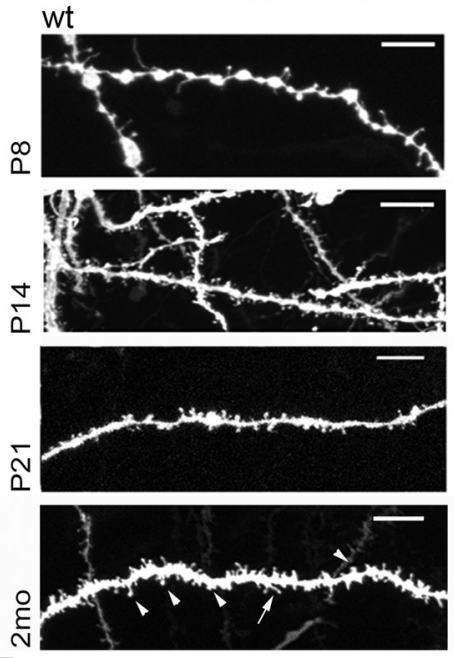

B

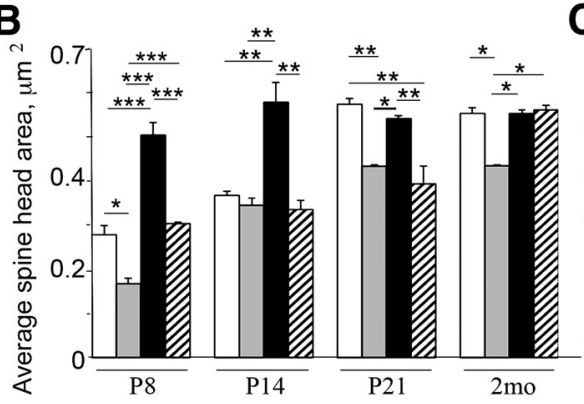

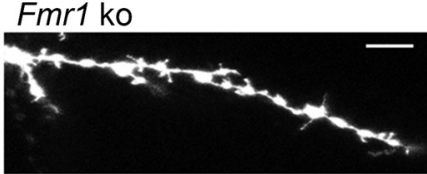


C

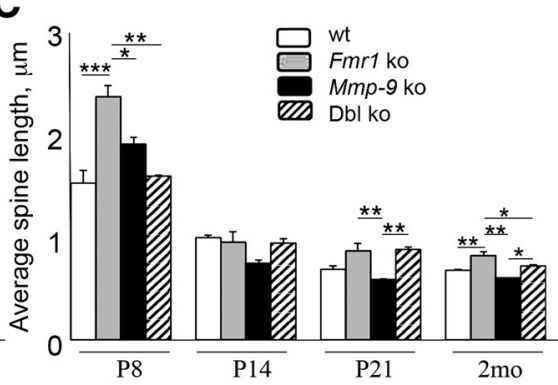

Mmp-9 ko
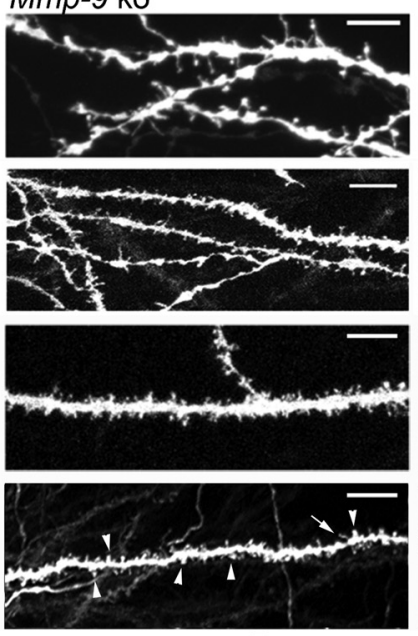

D

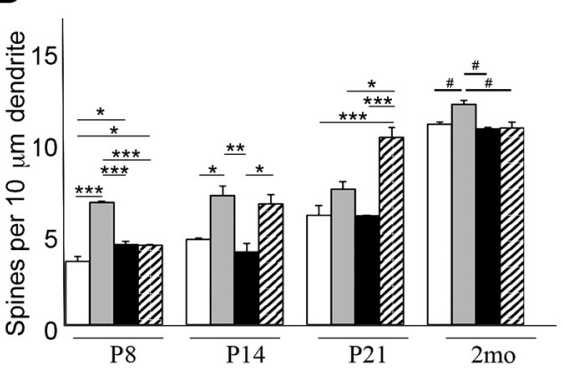

Figure 3. Hippocampal neurons develop normal mature dendritic spines in the Fmr1/Mmp-9 dbl ko mice in vivo. A, Confocal images of Dil-labeled dendrites of wt, Fmr 1 ko, Mmp- 9 ko, and dbl ko hippocampal neurons from CA1 stratum radiatum at P8,P14, P21, and 2 months. Arrowheads denote mature mushroom-shaped spines, and arrows mark immature thin spines. Scale bars, $10 \mu \mathrm{m}$. $\boldsymbol{B}-\boldsymbol{D}$, Quantitative analysis of average spine head areas $(\boldsymbol{B})$, spine lengths $(\boldsymbol{C})$, and density (D) in CA1 hippocampal neurons of wt, Fmr 1 ko, Mmp-9 ko, and dbl ko mice at P8, P14, P21, and 2 months. Error bars indicate SEM ( $n=3$ mice per group). Statistical analysis was performed using two-way ANOVA followed by Bonferroni multiple-comparison post-test: ${ }^{*} p<0.05$, ${ }^{* *} p<0.01,{ }^{* * *} p<0.001$. Spine density in 2-month-old Fmr 1 ko neurons was significantly higher than in the other three groups with tw0-way ANOVA followed by Fisher's LSD method of multiple comparisons: \#p $<0.05$.

the number of filopodia, and a higher proportion of mature mushroom-shaped spines in Fmr1/Mmp-9 dbl ko hippocampal neurons compared with Fmrl ko neurons $(p<0.0001$; Fig. $2 B, D, E)$. Interestingly, MMP-9-deficient neurons exhibited significantly shorter spines than wt mice ( $p=0.0122$; Fig. $2 C$ ). However, hippocampal neurons from dbl ko mice showed no significant differences in the number and morphology of dendritic spines compared with wt mice (Fig. 2A$E)$. While dbl ko neurons developed more mature spines with larger heads and fewer filopodia than Fmr1 ko neurons, the overall number of presynaptic inputs did not change $(p=0.8638$; Fig. $2 F)$. The increase in the number of mushroom-shaped spines accompanied a corresponding decrease in the number of thin spines (Fig. $2 E$ ), indicating that MMP-9 deletion promotes spine maturation in dbl ko neurons. These observations establish that MMP-9 contributes to dendritic spine abnormalities in Fmr1 ko neurons, as normal dendritic spine maturation was restored in Fmr1 ko mice lacking the Mmp-9 gene.
A Electrophysiology

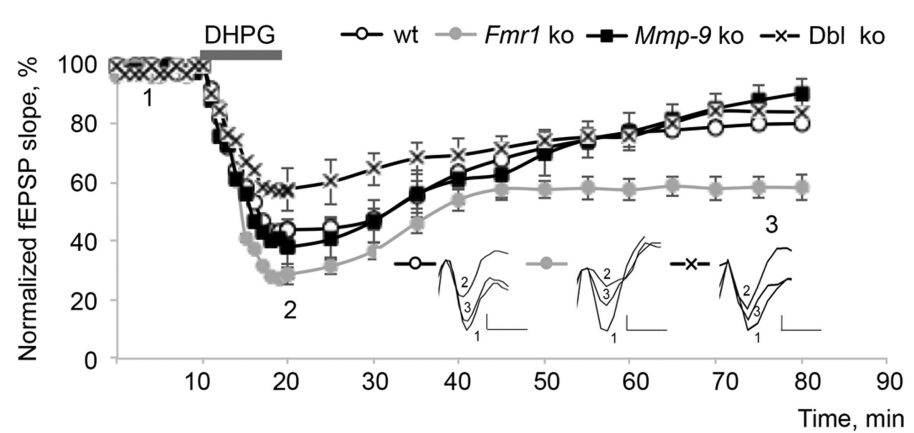

B

Figure 4. Genetic deletion of Mmp-9 ameliorates enhanced DHPG-dependent LTD in hippocampal slices from Fmr 1 ko mice. $\boldsymbol{A}$, $B$, LTD of Schaffer collateral-CA1 synapses was evoked by the application of $100 \mu \mathrm{M}$ DHPG for $10 \mathrm{~min}$ in hippocampal slices from wt, $F m r 1 \mathrm{ko}, M m p-9$ ko, and dbl ko mice. Field EPSPs were recorded for 10 min before the induction to establish a baseline and 60 min after DHPG removal at 0.5 min interval. The fEPSPs were normalized to baseline. $A$, The graph shows mean and SEM values ( $n=11-17$ slices from 6 mice per group). Inset, 0 verlaid representative fEPSP traces collected during baseline (1), immediately after DHPG treatment (2), and 60 min after DHPG treatment (3) for wt, $F m r 1$ ko, and dbl ko mice. Calibration: $50 \mathrm{mV}, 2 \mathrm{~ms}$. B, Bar graph shows mean normalized fEPSP values for 65-80 min. Error bars indicate SEM. Statistical analysis was performed using two-way ANOVA followed by Bonferroni multiple-comparison post-test: ${ }^{* *} p<0.01$, ${ }^{* * *} p<0.001$.

Genetic deletion of $M m p-9$ rescues Fmr1 ko-associated dendritic spine abnormalities in adult hippocampus To determine whether MMP-9 deficiency could prevent dendritic spine defects resulting from FMRP loss in vivo, we analyzed 


\section{A Open field test}
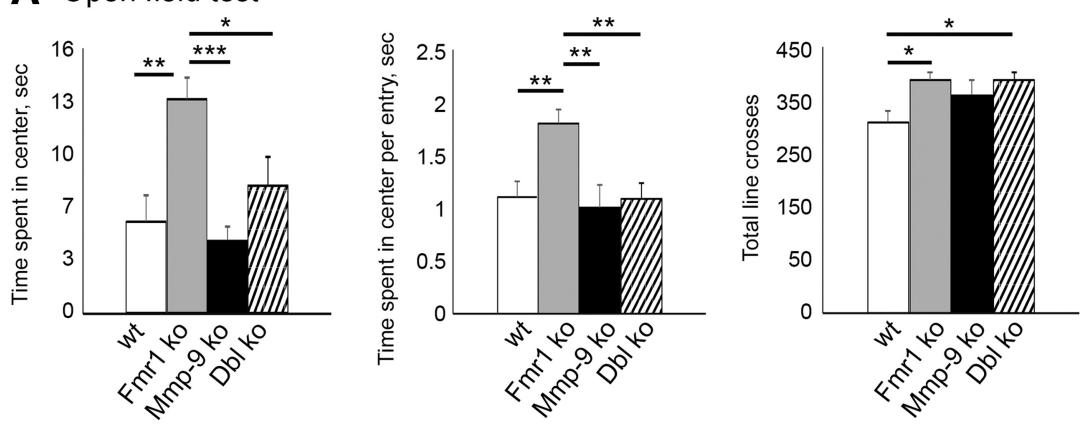

B Social interactions test


\section{Macroorchidism}
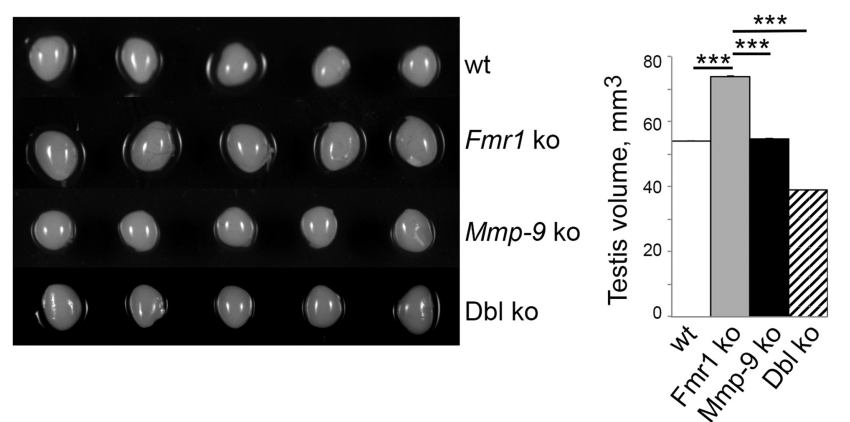

Figure 5. Behavioral deficits and macroorchidism are ameliorated in the dbl ko mice. $\boldsymbol{A}$, The open field test was performed to measure anxiety and hyperactivity in wt, Fmr1 ko, Mmp-9 ko, and dbl ko mice. Bar graphs show the time that mice spent in the center of the open field (left), the time spent in the center per entry (middle), and the total number of line crosses (right). The bar graphs represent average values, and the error bars indicate SEM $(n=11-17$ mice per group). Statistical analysis was performed using two-way ANOVA followed by Newman-Keuls correction for multiple comparisons post-test: ${ }^{*} p<0.05,{ }^{* *} p<0.01,{ }^{* * *} p<0.001 . B$, To measure social interaction behavior, we tested the time that mice spent with $\$ 1$ compared with an empty cage ( - ) during session 1 and the time that mice spent with S2 compared with now familiar S1 during session 2. The bar graphs represent average values, and the error bars indicate SEM ( $n=13-30$ mice per group). Statistical analysis was performed using two-way ANOVA followed by a Bonferroni multiplecomparison post-test: ${ }^{*} p<0.05,{ }^{* *} p<0.01,{ }^{* * *} p<0.001$. ns, Nonsignificant. C, Images showing representative testes isolated from wt, Fmr 1 ko,Mmp-9ko, and dbl ko month-old mice (left). The bar graphs show average values of the testicular volume (middle) and testicular weight (right). Error bars indicate SEM ( $n=12$ testes from 6 mice per group). Statistical analysis was performed using two-way ANOVA followed by Bonferroni multiple-comparison post-test: ${ }^{* * *} p<0.001$.

spine numbers and morphology in wt, Fmr1 ko, Mmp-9 ko, and dbl ko mice at P8, P14, P21, and P60 (adults; Fig. 3A-D). We found a significant reduction in the size of spine heads, as well as an increase in spine length and density in CA1 hippocampal neurons of both developing and adult Fmr1 ko mice (Fig. 3B-D). Interestingly, $M m p-9$ deletion triggered an early increase in spine size with significantly larger spine heads in $\mathrm{Mmp}-9$ ko neurons at P8 and P14 ( $p<0.001$; Fig. $3 B)$. However, P8 neurons lacking both Fmr1 and Mmp-9 (dbl ko neurons) exhibited normal spines that were not significantly different from wt neurons (Fig. $3 B, C$ ). Dendritic spines in dbl ko neurons were significantly shorter, had

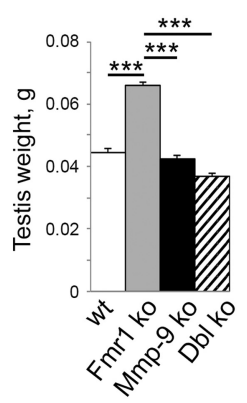

larger heads, and were fewer in number than in Fmr1 ko neurons at P8 $(p<0.001$, Fig. $3 B-D$ ), but the spine heads in $\mathrm{dbl}$ ko neurons were smaller than in $M m p-9$ ko neurons $(p<0.001)$. Although at P21 spine heads were smaller in both Fmr1 ko and dbl ko neurons than in wt neurons, at 2 months of age dbl ko neurons exhibited spines that were similar to those in wt neurons with larger heads and shorter lengths than Fmr1 ko neurons ( $p=$ 0.0263 and $p=0.0402$; Fig. $3 B, C)$. There were also fewer spines in adult dbl ko neurons compared with Fmrl ko neurons $(p<0.05$; Fig. 3D). Together, these results indicate that MMP-9 regulation is involved in the development and maintenance of dendritic spines in vitro and in vivo, and that enhanced MMP-9 activity may contribute to abnormal development of dendritic spines in Fmr1 ko neurons.

\section{Genetic deletion of $M m p-9$ ameliorates enhanced mGluR5-dependent LTD in hippocampal slices of Mmp-9/Fmr1 ko mice}

We examined LTD in hippocampal slices from wt, Fmr1 ko, Mmp-9 ko, and dbl ko mice, induced by bath application of the mGluR5 agonist DHPG for $10 \mathrm{~min}$. A depression of the fEPSP was found in all four groups, but was significantly greater in Fmrl ko mice (58\%), 60 min after DHPG washout, compared with wt $(79 \%, p=$ $0.0022)$, Mmp-9 ko (86\%, $p<0.0001)$, and dbl ko mice $(83 \%, p=0.0001$; Fig. $4 A, B)$. These results indicate that MMP-9 impacts mechanisms that underlie enhanced mGluR5-induced LTD in Fmr1 ko mice since genetic deletion of $M m p-9$ prevents that deficit.

Behaviors in open field and social novelty preference tests are improved in Mmp-9/Fmr1 dbl ko mice

We assessed anxiety and locomotor activity in the open field test by determining the tendency of mice to travel to the center of the open field and total line crosses, respectively (Fig. 5A). We found that Fmr1 ko mice displayed an increased tendency to travel to the center of the open field and also had enhanced locomotor activity (Fig. 5A). Fmr1 ko mice spent significantly more time in the center of the open field than wt mice ( $p<0.01$; Fig. $5 A$, left) and less time in thigmotaxis. Although Fmr1 ko mice were more hyperactive and made more line crosses than wt mice ( $p<0.05$; Fig. $5 A$, right), Fmr1 ko mice also spent more time in the center per entry than wt mice $(p<$ 0.01 ; Fig. $5 A$, middle). $M m p-9$ deletion reduced the tendency of Fmrl ko mice to travel to the center of the open field. The dbl ko mice spent significantly less time per center entry and less total time in the center of the open field than Fmr1 ko mice $(p<0.01$ and $p<0.05$; Fig. 5A, left and middle); however, dbl ko mice 

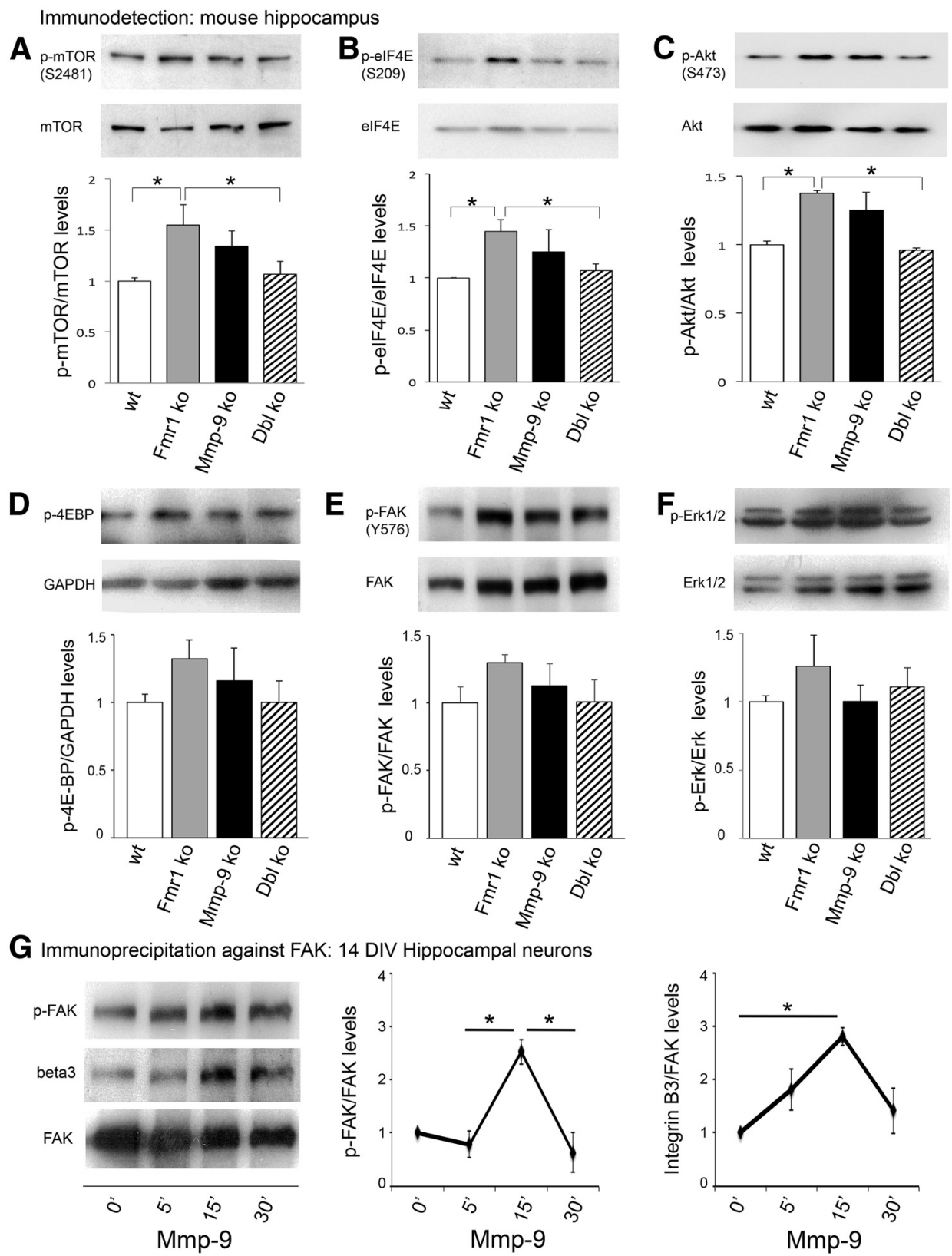

G Immunoprecipitation against FAK: 14 DIV Hippocampal neurons

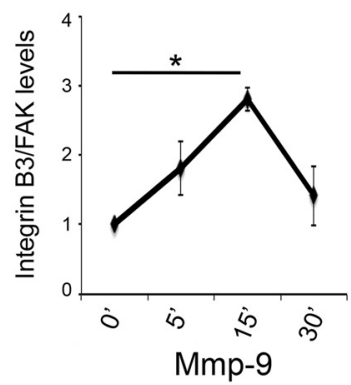

H Immunodetection: 14 DIV Hippocampal neurons
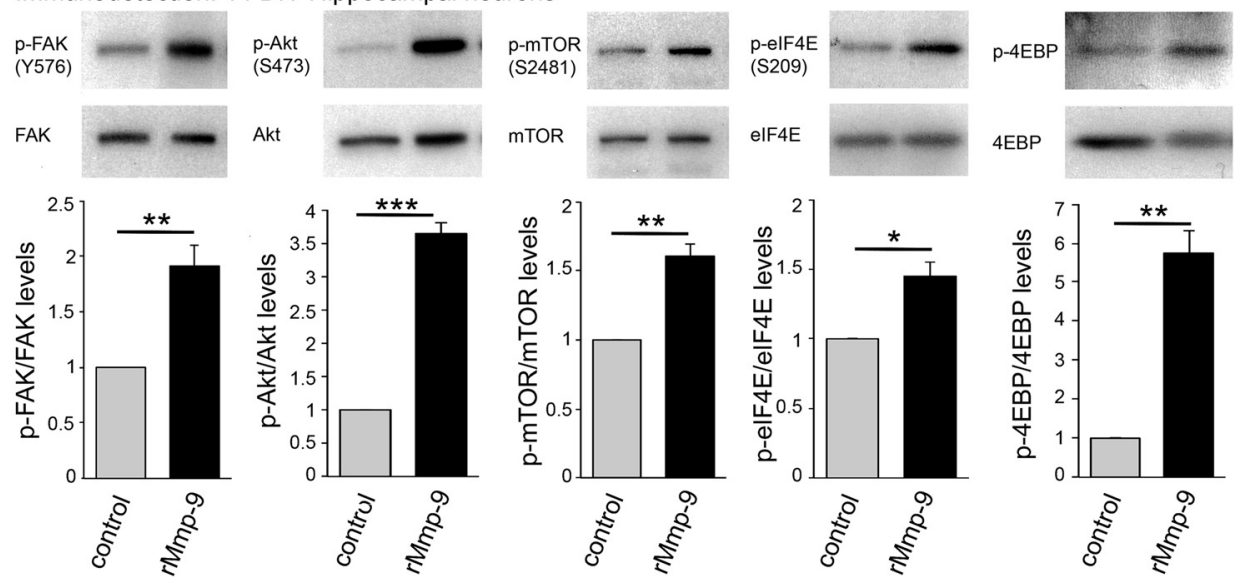

Figure 6. Increased Akt, mTOR, and elF4E phosphorylation in Fmr1 ko mice is reduced by MMP-9 deletion. $\boldsymbol{A}-\boldsymbol{E}$, Western blots were used to quantify phosphorylated and total levels of specific proteins. $\boldsymbol{A}-\boldsymbol{F}$, The bar graphs show phospho/total ratios of mTOR $(\boldsymbol{A})$, elF4E $(\boldsymbol{B})$, Akt $(\boldsymbol{C}), 4 \mathrm{E}-\mathrm{BP}(\boldsymbol{D})$, FAK $(\boldsymbol{E})$, and Erk1/2 $(\boldsymbol{F})$ in the hippocampi of wt, $($ Figure legend continues.) 
made more total line crosses than wt mice $(p<0.05$; Fig. $5 A$, right). Fmrl ko and dbl ko mice also exhibited higher overall velocities compared with wt mice.

A major feature of FXS is reduced socialization. To determine whether MMP-9 contributes to this behavior in Fmrp-deficient mice, we tested dbl ko, Fmrl ko, Mmp-9 ko, and wt mice in a social novelty test. Mice were placed in an enclosure that contained two smaller cages for two 10 min sessions. In session 1, an unfamiliar mouse (S1) was placed in one of the smaller cages. All mice spent significantly more time near the stranger mouse cage than the empty cage ( $p<0.0001$; Fig. 5B, left). However, Fmr1 ko mice spent significantly more time near the empty cage than wt mice $(p=0.0170$; Fig. $5 B$, left). In the second session, another mouse (S2) was placed in the empty cage, so the subject mouse could choose to interact with a familiar mouse (S1) or a new mouse (S2). The wt, Mmp-9 ko, and $\mathrm{dbl}$ ko mice spent significantly more time with the novel mouse (S2) than the familiar mouse (S1; $p<0.0001$; Fig. $5 B$, right), but Fmrl ko mice spent the same amount of time with both S1 and S2 mice, suggesting they could not or would not discriminate between familiar and novel mice. Importantly, the loss of Mmp-9 in Fmrl ko mice (dbl ko) corrected this defect.

\section{Fmr1 ko animals display macroorchidism that is ameliorated by MMP-9 deficiency}

To determine whether high levels of MMP-9 activity might also contribute to the characteristic physical traits associated with FXS, we examined macroorchidism in Fmrl ko, Mmp-9 ko, dbl ko, and wt mice. Testes from Fmrl ko mice appeared visibly larger than those of wt mice (Fig. 5C, left). Measurement of volume and weight showed that Fmrl ko testes were significantly larger than testes in wt or Mmp-9 ko mice ( $p<0.0001$; Fig. $5 C$, middle and right). Remarkably, testes from dbl ko mice were significantly smaller than those of Fmr1 ko mice ( $p<0.0001$; Fig. $5 C)$.

\section{MMP-9 deficiency reduces Akt, mTOR, and eIF4E phosphorylation in Fmr1 ko mice}

To investigate intracellular signaling cascades that could mediate the effects of enhanced MMP-9 activity in Fmrl ko neurons, we examined mTOR, eIF4E, 4E-BP, Akt, and FAK activation in dbl ko mice by assessing phosphorylation levels of these proteins. Higher levels of the phosphorylated (i.e., active) forms of all three proteins were detected in the hippocampus of adult Fmrl ko mice, compared with wt mice. Specifically, there was a $50 \%$ increase in the $\mathrm{p}-\mathrm{mTOR} / \mathrm{mTOR}$ ratio in the Fmrl ko mice $(p=$ 0.0171), but in dbl ko mice p-mTOR was at the same levels as in wt mice and was significantly lower than in Fmrl ko mice ( $p=$ 0.0319; Fig. 6A). This same effect was also seen for the p-eIF4E/

\footnotetext{
(Figure legend continued.) Fmr1 ko, Mmp-9 ko, and dbl ko mice. The bar graphs represent average values, and error bars indicate SEM ( $n=4$ mice per group). Statistical analysis was performed using two-way ANOVA with Fisher's LSD method: $\left.{ }^{*} p<0.05\right)$. G, The 14 DIV hippocampal neurons were treated with $100 \mathrm{ng} / \mathrm{ml}$ active MMP-9 for 5, 15 , or $30 \mathrm{~min}$. Immunoprecipitation and Western blot analysis were performed to detect levels of pFAK and integrin- $\beta 3$ in association with FAK in untreated and MMP-9-treated cultures. Graphs show the levels of pFAK and integrin- $\beta 3$ associated with FAK at 0,5 , 15, or 30 min after MMP-9 treatment. Statistical analysis was performed using one-way ANOVA followed by Tukey's post hoc test: ${ }^{*} p<0.05$. H, The 14 DIV wt hippocampal neurons were treated with $100 \mathrm{ng} / \mathrm{ml}$ active MMP-9 for $15 \mathrm{~min}$. Western blot analysis was performed to detect phosphorylated and total levels of specific proteins. The bar graphs show phospho/total ratios of FAK, Akt, mTOR, elF4E and $4 \mathrm{E}-\mathrm{BP}$ in control-treated and MMP-9 treated cultures. The bar graphs represent average values, and error bars indicate SEM ( $n=3$ cultures per group). Statistical analysis was performed using Student's $t$ test: ${ }^{*} p<0.05,{ }^{* *} p<0.01,{ }^{* * *} p<0.001$.
}

eIF4E ratio, which was 50\% higher in the Fmrl ko mice, compared with wt mice, and was $30 \%$ lower in dbl ko mice compared with Fmrl ko mice ( $p=0.0133$ and $p=0.0202$ respectively; Fig. $6 B)$. Fmrl ko mice also had a $30 \%$ increase in p-Akt/Akt ratio compared with wt $(p=0.0255)$ and dbl ko mice $(p=0.0179)$, suggesting that Akt activation may mediate the effects of MMP-9 on mTOR and eIF4E phosphorylation levels (Fig. 6C). Thirty percent increases were also seen in phosphorylation levels of FAK and the eIF4E binding partner 4E-BP in Fmrl ko mice compared with wt mice, which were reduced to near normal levels in dbl ko mice, although the differences were not statistically significant due to large variations between the samples (Fig. $6 D, E$, respectively). MAP kinase Erk1/2 activity was not affected by the deletion of MMP-9 (Fig. $6 F$ ). Since MMP-9 is a secreted extracellular protein, it suggests that signaling effector activation is mediated by MMP-9 impacting a cell surface receptor, a primary candidate being the integrin family of ECM receptors. Western blotting revealed a transient increase in the levels of the activated, phosphorylated form of FAK (Fig. $6 G$ ) and a significant increase in the association of FAK with integrin- $\beta 3$ subunit, but not EphB2 receptor in 14 DIV hippocampal neurons after 15 min of MMP-9 treatment (Fig. 6G). These results suggest that MMP-9 cleavage of the ECM initiates an integrin signaling cascade that leads to the activation of intracellular signaling cascades involving Akt, mTOR, and eIF4E, leading to the changes in translational activity (Figs. 6, 7). Indeed, we observed significant increases in phosphorylation levels of FAK $(p=0.0019)$, Akt $(p=0.0002)$, $\operatorname{mTOR}(p=0.0084)$, eIF4E $(p=0.0375)$, and $4 \mathrm{E}-\mathrm{BP}(p=0.001)$ following the treatment of wt hippocampal neurons with active MMP-9 (Fig. 6H).

\section{Discussion}

Minocycline promotes dendritic spine maturation and improves FXS-associated behaviors in both Fmrl ko mice and FXS subjects (Bilousova et al., 2009; Paribello et al., 2010; Rotschafer et al., 2012; Dansie et al., 2013; Leigh et al., 2013; Schneider et al., 2013). Pharmacological studies in Fmrl ko mice suggest that MMP-9 inhibition as a possible mechanism of action for minocycline in FXS (Bilousova et al., 2009). Here we provide further evidence that MMP-9 dysregulation contributes to FXS-associated defects, including aberrant dendritic spine maturation, enhanced mGluR5-dependent LTD, poor socialization, and macroorchidism. In sharp contrast to Fmrl ko mice, dbl ko mice show normal dendritic spine development, LTD, social preference behavior, and testicular size. Using genetics, we have validated the importance of MMP-9 expression in FXS by showing that most defects associated with FMRP deficiency do not occur in the brains and testes of Mmp-9/Fmr1 dbl ko mice.

High levels of MMP-9 activity could account for FXSassociated defects through several possible mechanisms (Ethell and Ethell, 2007). MMPs were initially discovered due to their proteolytic activity on ECM components, many of which impact dendritic spine development and plasticity (Ethell and Ethell, 2007; Dziembowska and Wlodarczyk, 2012; Huntley, 2012). Neurons are supported by perineuronal nets (PNNs) comprised of loose ECM components that participate in neuronal function (Brückner et al., 2000; Dansie and Ethell, 2011; Wlodarczyk et al., 2011), and MMP-9-mediated cleavage of PNN components could modulate synaptic structure and function (Nagy et al., 2006; Bozdagi et al., 2007; Szepesi et al., 2013). MMP-9-mediated release of arginine-glycine-aspartate (RGD)-containing peptides from ECM components, such as laminin, could induce integrin activation in perisynaptic areas and trigger synapse remodeling (Shi and Ethell, 2006). Indeed, MMP-9 regulates synaptic plasticity 
and NMDAR currents through integrin signaling (Meighan et al., 2006; Nagy et al., 2006). Integrins are powerful regulators of the actin cytoskeleton and could also mediate the effects of MMP-9 on dendritic spine morphology (Moeller et al., 2006; Wang et al., 2008).

Dendritic spine size directly correlates with the size of the postsynaptic density (Tashiro and Yuste, 2003). Several groups have previously reported an abundance of immature dendritic spines with small heads in the hippocampi of adult Frm 1 ko mice (Bhattacharya et al., 2012; Lauterborn et al., 2013). Interestingly, a greater number of thin spines and overall higher spine density were observed in the hippocampus of adult Frm1 ko mice than WTs when the mice were housed in an enriched environment (Lauterborn et al., 2013). Immature thin spines with small heads, which are also abundant in human subjects with FXS, usually display fewer AMPARs in the postsynaptic density (Matsuzaki et al., 2001). Synaptic plasticity is dependent on AMPAR levels at postsynaptic spines, and both are regulated by cytoskeletal changes and protein synthesis. For example, increased translation of Arc induces AMPAR internalization in Fmrl ko mice (Bagni et al., 2012) and may contribute to enhanced mGluR5-induced LTD and impaired LTP in Fmrl ko mice (Huber et al., 2002; Lauterborn et al., 2007). Enhanced hippocampal mGluR5dependent LTD was suggested to underlie cognitive and behavioral defects in Fmr1 ko mice and FXS subjects (Huber et al., 2002; Michalon et al., 2012). In the absence of FMRP, type I mGluR expression is higher and more AMPARs are internalized before glutamate signaling, thereby lengthening LTD (Bear et al., 2004; Hou et al., 2006; Oostra and Willemsen, 2009). The resulting hyperactivity of type I mGluRs has been shown to contribute to enhanced LTD since receptor antagonists, including MPEP, Fenobam, and CTEP, block this increase and alleviate some FXS-associated behaviors in Fmrl ko mice and FXS human subjects (Yan et al., 2005; Michalon et al., 2012). Alternatively, it has been proposed that FMRP deficiency alters GABA receptor subunit composition, thereby lowering GABAergic inputs to hippocampal circuits (D'Hulst et al., 2009). GABA receptor agonists, such as baclofen and nipecotic acid, partially rescue FXS-associated behaviors in mice (Pacey et al., 2009; Levenga et al., 2011). In this study, we also observed enhanced mGluR5-dependent LTD in the hippocampus of Fmrl ko
A

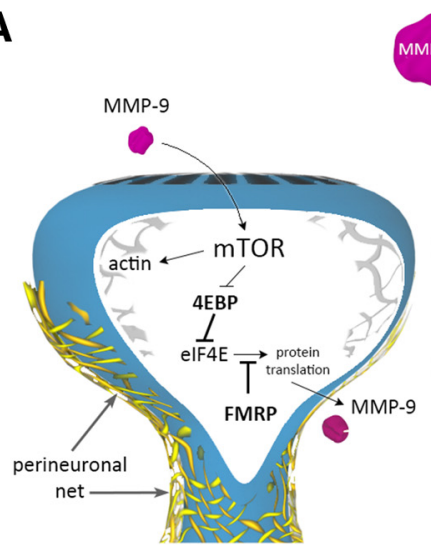

wild-type

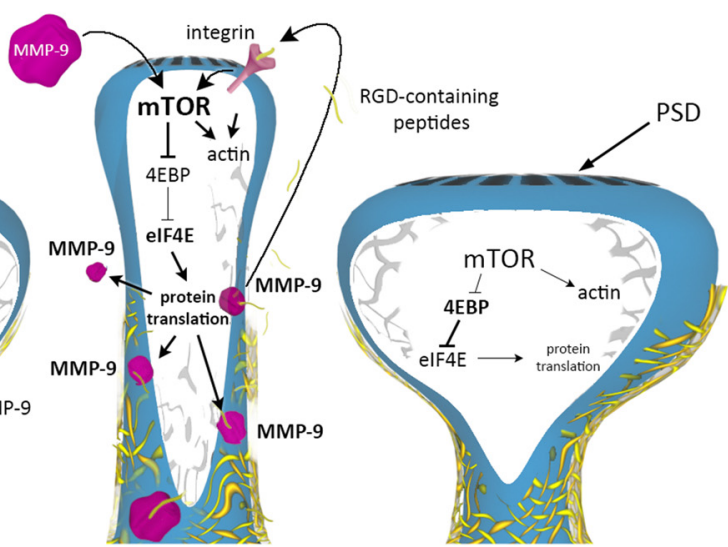

Fmr1 ko
Fmr1/Mmp9 ko
B

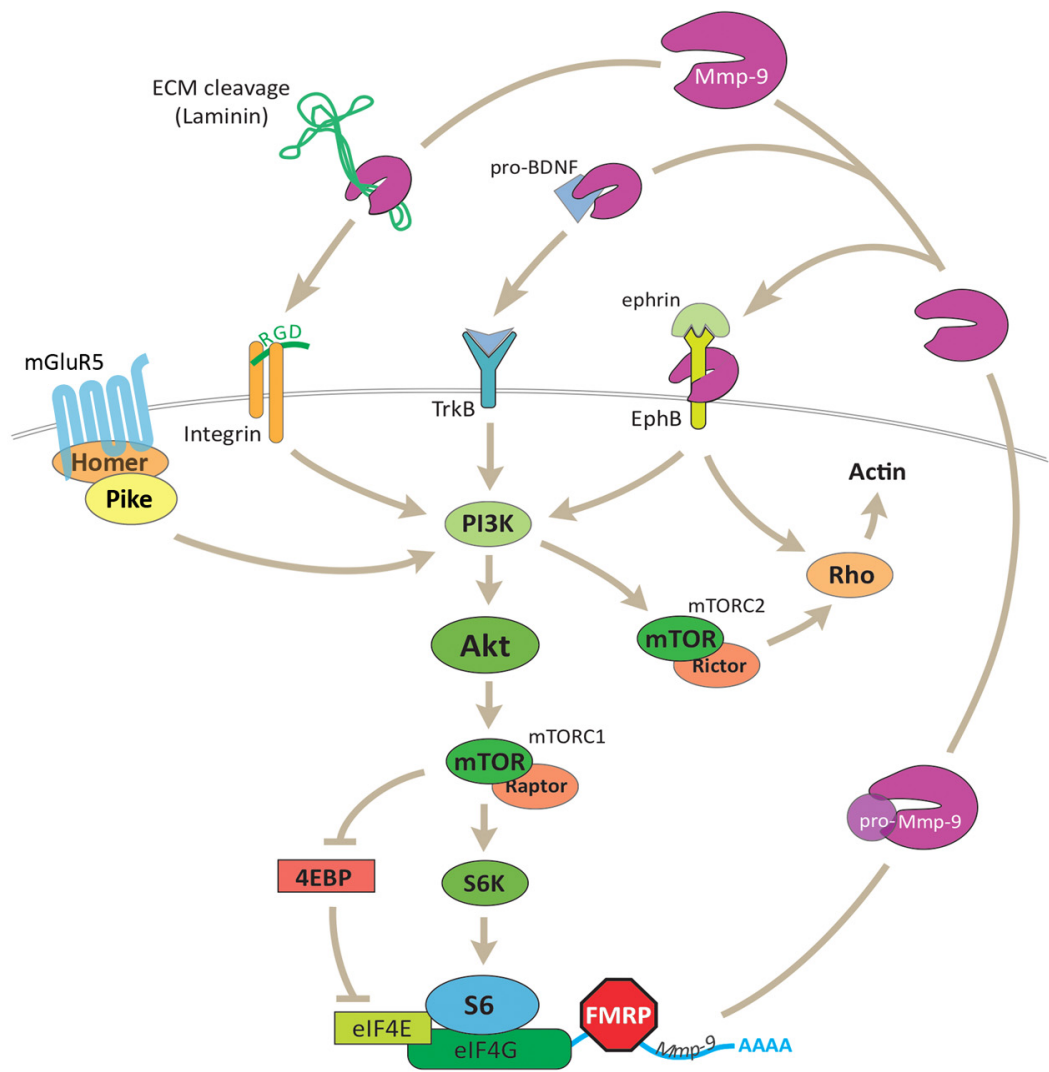

Figure 7. Schematic depiction of MMP-9 effects in dendritic spines. $\boldsymbol{A}$, Schematic of key processes that impact dendritic spine morphology in wt, Fmr1 ko, and dbl ko mice. Left, Dendritic spines in wt mice that express FMRP exhibit mature morphology and normal levels of MMP-9. Middle, The absence of FMRP in Fmr 1 ko mice results in excess MMP-9 production, leading to excessive degradation of the perineuronal nets (yellow) and release of RGD-containing peptides that activate integrins. Excessive integrin signaling contributes to an increase in mTOR signaling, protein translation, and actin remodeling, leading to the formation of immature spines. Right, Genetic deletion of $M m p-9$ normalizes spine morphology and mTOR signaling in Fmr1/Mmp-9 dbl ko neurons. B, Bottom, The translation of Mmp-9 is regulated by FMRP. Right, When Fmr1 is absent, more pro-MMP-9 is produced and released into extracellular spaces. The activation of MMP-9 allows it to cleave the ephrinB receptor, EphB, and pro-BDNF to release BDNF, which binds to TrkB. Active MMP-9 also cleaves ECM components releasing RGD-containing peptides (green) that trigger integrin signaling. TrkB and integrin signaling increase PI3K activity, which increases Akt phosphorylation and activity. MMP-9 effects on EphB receptor signaling impact actin dynamics through Rho GTPases. Higher levels of PI3K can also impact actin dynamics through the mTORC2 complex, which also affects Rho kinases and the actin cytoskeleton. High levels of p-Akt increase mTORC1 complex activation, blocking 4EBP and inducing S6K, which increase mRNA translation through elF4E and S6, respectively. Hence Mmp-9 mRNA is translated more actively, and the MMP-9 gene product amplifies the loop. The association of the metabotropic glutamate receptor mGluR5 with a short form of Homer 1a leads to increased PI3K activity, adding to the same loop. 
mice, but the accompanying genetic disruption of Mmp-9 prevented this enhancement of LTD in dbl ko mice. Higher levels of MMP-9 may affect AMPAR trafficking during LTD by regulating the actin cytoskeleton through integrin signaling.

Although many MMP-9 substrates occur in and around CNS synapses (Ethell and Ethell, 2007), integrins and Eph receptors are the most likely candidates to mediate MMP-9 effects in Fmr1 ko neurons (Fig. 7). Both integrins and EphB receptors are known to signal through the recruitment and activation of FAK, Src, and the PI3K/Akt cascade (Moeller et al., 2006; Chen et al., 2009; Legate et al., 2009; Maddigan et al., 2011; Yu et al., 2012). Moreover, $\beta 1$ integrin negatively regulates the activity of protein phosphatase 2A, which dephosphorylates and inactivates Akt (Nho and Kahm, 2010). BDNF signaling through TrkB-PI3KAkt could also contribute to enhanced mTOR phosphorylation since BDNF levels are higher in the hippocampus of Fmr1 ko mice and mRNA for the high-affinity BDNF receptor $(\operatorname{TrkB})$ is a known target of FMRP (Louhivouri et al., 2011; Uutela et al., 2012). Notably, MMP-9 has been shown to cleave pro-BDNF (Hwang et al., 2005; Yang et al., 2009). PI3K-Akt-mTOR signaling is implicated in FXS and is known to regulate protein synthesis through elongation factor $1 \alpha$ (Hou and Klann, 2004; Ronesi and Huber, 2008; Gross et al., 2010; Sharma et al., 2010; Hoeffer et al., 2012). Although mGluR-dependent LTD depends on protein synthesis in wild-type mice, in Fmrl ko mice mGluRdependent LTD was reported to be protein synthesis independent, most likely due to an increase in basal levels of protein synthesis that disrupt mGluR-dependent translational control (Nosyreva and Huber, 2006). Changes in mGluR scaffold through its association with a short form of Homer 1a and increased PI3K signaling were attributed to coupling mGluR to mTORC1 in Fmrl ko mice (Ronesi et al., 2012). Restoring protein synthesis by inhibiting PI3K or the genetic deletion of S6 kinase 1 (S6K1) have been shown to correct mGluR-dependent LTD, abnormal spine morphology, and several behavioral abnormalities in Fmr1 ko mice (Gross et al., 2010; Bhattacharya et al., 2012). Our results suggest that reduced activation of downstream effectors of mGluR5-dependent translation, such as mTOR and eIF4E, due to the loss of MMP-9 may be responsible for the normalization of mGluR-dependent responses in $\mathrm{dbl}$ ko mice. It is also possible that the mGluR/Homer scaffold could be regulated via MMP-9-dependent changes in actin cytoskeletal organization (Ethell and Ethell, 2007).

Our results establish that MMP-9 deletion returns phosphorylation of mTOR and eIF4E to normal levels in dbl ko mice, likely due to the changes in Akt activity, which is also normalized in $\mathrm{dbl}$ ko mice (Fig. 6). In contrast, MAP kinase Erk1/2 activity was not affected by the deletion of MMP-9. In FXS, the absence of FMRP has been shown to result in increased eIF4E phosphorylation (Furic et al., 2010; Bagni et al., 2012). FMRP also regulates MMP-9 mRNA localization and translation by binding to and suppressing the translation of MMP-9 mRNA (Janusz et al., 2013). Activation of mGluR5 triggers FMRP dissociation from $M m p-9$ mRNA and promotes $M m p-9$ translation, suggesting that FMRP may act as a negative regulator of MMP-9 translation in neurons (Janusz et al., 2013). Excessive MMP-9 can activate Aktmediated signaling to further enhance mTOR, which in turn can phosphorylate 4E-BP2 and disinhibit eIF4E (Fig. 7). Dissociation of eIF4E from 4E-BP2 and CYFIP1 would further enhance protein translation, leading to excessive protein synthesis in the brain of Fmr1 ko mice, and shift CYFIP1 into the WAVE regulatory complex that regulates actin polymerization in dendritic spines (Napoli et al., 2008; De Rubeis et al., 2013; Udagawa et al., 2013).
Activation of mTOR can also regulate the activity of p70 ribosomal S6K1, which has been shown to regulate protein synthesis in Fmr1 ko mice (Bhattacharya et al., 2012).

Outside of the brain, FMRP is also highly expressed in the testis, where it regulates the translation of target mRNAs. Interestingly, Mmp-9 deletion rescues FXS-associated macroorchidism in dbl ko mice establishing for the first time a critical role for excess MMP-9 activity in this phenotype. SlegtenhorstEegdeman et al. (1998) reported higher Sertoli cell proliferation in the testis of Fmr1 ko mice. Sertoli cells produce MMP-9 and TIMP-1, and MMPs are known to cleave type IV collagen and increase the permeability of the blood-testis barrier, which permits the migration of the developing spermatocytes (Fritz et al., 1993; Robinson et al., 2001; Siu et al., 2003). Increased MMP-9 levels might affect basement membrane permeability and increase the number of migrating spermatocytes. High MMP-9 activity may also influence the proliferative capacity of the Sertoli and/or germ cells, contributing to increased testicular size (macroorchidism). Characteristic physical traits of FXS subjects are associated with connective tissue in joints, skin, ears, testes, and other areas. The correction of FXS-associated macroorchidism by MMP-9 deficiency implicates MMP-9 dysregulation in those physical traits. This gonadal link between MMP-9 and FXS may also extend to women, as many mothers of FXS sons carry FMR1 premutations and often develop premature ovarian insufficiency, by an unknown mechanism. It is possible that excessive MMP-9 causes gonad abnormalities in FMRP-deficient males and mosaic females. This relationship between Fmrp and Mmp-9 has also been observed in a Drosophila model of FXS where overexpression of Timp1 (an endogenous MMP regulator) or a $m m p$-null mutation rescued some of the defects that occur in $d f m r$-null flies, establishing a genetic link between these two genes (Siller and Broadie, 2011).

Here we have shown that enhanced MMP-9 activity is a central mediator of neural and non-neural defects associated with FMRP deficiency-the cause of FXS. The lack of MMP-9 in Fmr1 ko mice (i.e., dbl ko) ameliorated neurological and behavioral deficits associated with Fmrp deficiency, as well as macroorchidism. These findings indicate that MMP-9-specific inhibitors are promising therapeutic agents for treating behavioral, cognitive, and non-neural aspects of FXS.

\section{References}

Bagni C, Tassone F, Neri G, Hagerman R (2012) Fragile X syndrome: causes, diagnosis, mechanisms, and therapeutics. J Clin Invest 122:4314-4322. CrossRef Medline

Bassell GJ, Gross C (2008) Reducing glutamate signaling pays off in fragile X. Nat Med 14:249-250. CrossRef Medline

Bear MF, Huber KM, Warren ST (2004) The mGluR theory of fragile X mental retardation. Trends Neurosci 27:370-377. CrossRef Medline

Bhattacharya A, Kaphzan H, Alvarez-Dieppa AC, Murphy JP, Pierre P, Klann E (2012) Genetic removal of p70 S6 kinase 1 corrects molecular, synaptic, and behavioral phenotypes in fragile X syndrome mice. Neuron 76 : 325-337. CrossRef Medline

Bilousova T. Rusakov D, Ethell DW, Ethell IM (2006) Matrix metalloproteinase-7 disrupts dendritic spines in hippocampal neurons through NMDA receptor activation. J Neurochem 97:44-56. CrossRef Medline

Bilousova TV, Dansie L, Ngo M, Aye J, Charles JR, Ethell DW, Ethell IM (2009) Minocycline promotes dendritic spine maturation and improves behavioral performance in the fragile X mouse model. J Med Genet 46: 94-102. CrossRef Medline

Blackwell E, Zhang X, Ceman S (2010) Arginines of the RGG box regulate FMRP association with polyribosomes and mRNA. Hum Mol Genet 19: 1314-1323. CrossRef Medline

Bozdagi O, Nagy V, Kwei KT, Huntley GW (2007) In vivo roles for matrix metalloproteinase-9 in mature hippocampal synaptic physiology and plasticity. J Neurophysiol 98:334-344. CrossRef Medline 
Braun K, Segal M (2000) FMRP involvement in formation of synapses among cultured hippocampal neurons. Cereb Cortex 10:1045-1052. CrossRef Medline

Brown RE, Corey SC, Moore AK (1999) Differences in measures of exploration and fear in MHC-congenic C57BL/6J and B6-H-2K mice. Behav Genet 29:263-271. CrossRef

Brückner G, Grosche J, Schmidt S, Härtig W, Margolis RU, Delpech B, Seidenbecher CI, Czaniera R, Schachner M (2000) Postnatal development of perineuronal nets in wild-type mice and in a mutant deficient in tenascin-R. J Comp Neurol 428:616-629. CrossRef Medline

Bureau I, Shepherd GM, Svoboda K (2008) Circuit and plasticity defects in the developing somatosensory cortex of FMR1 knock-out mice. J Neurosci 28:5178-5188. CrossRef Medline

Chen ZL, Haegeli V, Yu H, Strickland S (2009) Cortical deficiency of laminin gammal impairs the AKT/GSK-3beta signaling pathway and leads to defects in neurite outgrowth and neuronal migration. Dev Biol 327:158-168. CrossRef Medline

Comery TA, Harris JB, Willems PJ, Oostra BA, Irwin SA, Weiler IJ, Greenough WT (1997) Abnormal dendritic spines in fragile X knockout mice: maturation and pruning deficits. Proc Natl Acad Sci U S A 94:5401-5404. CrossRef Medline

Cruz-Martín A, Crespo M, Portera-Cailliau C (2010) Delayed stabilization of dendritic spines in fragile X mice. J Neurosci 30:7793-7803. CrossRef Medline

Dansie LE, Ethell IM (2011) Casting a net on dendritic spines: the extracellular matrix and its receptors. Dev Neurobiol 7:956-981. CrossRef Medline

Dansie LE, Phommahaxay K, Okusanya AG, Uwadia J, Huang M, Rotschafer SE, Razak KA, Ethell DW, Ethell IM (2013) Long-lasting effects of minocycline on behavior in young but not adult fragile $\mathrm{X}$ mice. Neuroscience 246:186-198. CrossRef Medline

Darnell JC, Van Driesche SJ, Zhang C, Hung KY, Mele A, Fraser CE, Stone EF, Chen C, Fak JJ, Chi SW, Licatalosi DD, Richter JD, Darnell RB (2011) FMRP stalls ribosomal translocation on mRNAs linked to synaptic function and autism. Cell 146:247-261. CrossRef Medline

De Rubeis S, Pasciuto E, Li K, Fernández E, Di Marino D, Buzzi A, Ostroff LE, Klann E, Zwartkruis FJ, Komiyama NH, Grant SG, Poujol C, Choquet D, Achsel T, Posthuma D, Smit AB, Bagni C (2013) CYFIP1 coordinates mRNA translation and cytoskeleton remodeling to ensure proper dendritic spine formation. Neuron 79:1169-1182. CrossRef Medline

D'Hulst C, Heulens I, Brouwer JR, Willemsen R, De Geest N, Reeve SP, De Deyn PP, Hassan BA, Kooy RF (2009) Expression of the GABAergic system in animal models for fragile $\mathrm{X}$ syndrome and fragile $\mathrm{X}$ associated tremor/ataxia syndrome (FXTAS). Brain Res 1253:176-183. CrossRef Medline

Dictenberg JB, Swanger SA, Antar LN, Singer RH, Bassell GJ (2008) A direct role for FMRP in activity-dependent dendritic mRNA transport links filopodial-spine morphogenesis to fragile X syndrome. Dev Cell 14:926939. CrossRef Medline

Dziembowska M, Wlodarczyk J (2012) MMP-9: a novel function in synaptic plasticity. Int J Biochem Cell Biol 44:709-713. CrossRef Medline

Dziembowska M, Pretto DI, Janusz A, Kaczmarek L, Leigh MJ, Gabriel N, Durbin-Johnson B, Hagerman RJ, Tassone F (2013) High MMP-9 activity levels in fragile $\mathrm{X}$ syndrome are lowered by minocycline. Am J Med Genet A 161A:1897-1903. CrossRef Medline

Ethell IM, Ethell DW (2007) Matrix metalloproteinases in brain development and remodeling: synaptic functions and targets. J Neurosci Res 85:2813-2823. CrossRef Medline

Feng Y, Gutekunst CA, Eberhart DE, Yi H, Warren ST, Hersch SM (1997) Fragile X mental retardation protein: nucleocytoplasmic shuttling and association with somatodendritic ribosomes. J Neurosci 17:1539-1547. Medline

Fiala JC, Feinberg M, Popov V, Harris KM (1998) Synaptogenesis via dendritic filopodia in developing hippocampal area CA1. J Neurosci 18: 8900-8911. Medline

Fritz IB, Tung PS, Ailenberg M (1993) Proteases and anti-proteases in the seminiferous tubule. In: The Sertoli cell (Russell LD, Griswold MD, eds), pp 217-235. Clearwater, FL: Cache River.

Furic L, Rong L, Larsson O, Koumakpayi IH, Yoshida K, Brueschke A, Petroulakis E, Robichaud N, Pollak M, Gaboury LA, Pandolfi PP, Saad F, Sonenberg N (2010) eIF4E phosphorylation promotes tumorigenesis and is associated with prostate cancer progression. Proc Natl Acad Sci U S A 107:14134-14139. CrossRef Medline

Garber KB, Visootsak J, Warren ST (2008) Fragile X syndrome. Eur J Hum Genet 16:666-672. CrossRef Medline

Gross C, Nakamoto M, Yao X, Chan CB, Yim SY, Ye K, Warren ST, Bassell GJ
(2010) Excess phosphoinositide 3-kinase subunit synthesis and activity as a novel therapeutic target in fragile X syndrome. J Neurosci 30:1062410638. CrossRef Medline

Hagerman R, Hagerman P (2013) Advances in clinical and molecular understanding of the FMR1 premutation and fragile X-associated tremor/ ataxia syndrome. Lancet Neurol 12:786-798. CrossRef Medline

Hagerman RJ, Berry-Kravis E, Kaufmann WE, Ono MY, Tartaglia N, Lachiewicz A, Kronk R, Delahunty C, Hessl D, Visootsak J, Picker J, Gane L, Tranfaglia M (2009) Advances in the treatment of fragile X syndrome. Pediatrics 123:378-390. CrossRef Medline

Hanson JE, Madison DV (2007) Presynaptic FMR1 genotype influences the degree of synaptic connectivity in a mosaic mouse model of fragile $\mathrm{X}$ syndrome. J Neurosci 27:4014-4018. CrossRef Medline

Hinton VJ, Brown WT, Wisniewski K, Rudelli RD (1991) Analysis of neocortex in three males with the fragile X syndrome. Am J Med Genet 41:289-294. CrossRef Medline

Hoeffer CA, Sanchez E, Hagerman RJ, Mu Y, Nguyen DV, Wong H, Whelan AM, Zukin RS, Klann E, Tassone F (2012) Altered mTOR signaling and enhanced CYFIP2 expression levels in subjects with fragile X syndrome. Genes Brain Behav 11:332-341. CrossRef Medline

Hou L, Klann E (2004) Activation of the phosphoinositide 3-kinase-Aktmammalian target of rapamycin signaling pathway is required for metabotropic glutamate receptor-dependent long-term depression. J Neurosci 24:6352-6361. CrossRef Medline

Hou L, Antion MD, Hu D, Spencer CM, Paylor R, Klann E (2006) Dynamic translational and proteasomal regulation of fragile $\mathrm{X}$ mental retardation protein controls mGluR-dependent long-term depression. Neuron 51: 441-454. CrossRef Medline

Huber KM, Gallagher SM, Warren ST, Bear MF (2002) Altered synaptic plasticity in a mouse model of fragile X mental retardation. Proc Natl Acad Sci U S A 99:7746-7750. CrossRef Medline

Huntley GW (2012) Synaptic circuit remodelling by matrix metalloproteinases in health and disease. Nat Rev Neurosci 13:743-757. CrossRef Medline

Hwang JJ, Park MH, Choi SY, Koh JY (2005) Activation of the Trk signaling pathway by extracellular zinc. Role of metalloproteinases. J Biol Chem 280:11995-12001. CrossRef Medline

Irwin SA, Galvez R, Greenough WT (2000) Dendritic spine structural anomalies in fragile-X mental retardation syndrome. Cereb Cortex 10: 1038-1044. CrossRef Medline

Janusz A, Milek J, Perycz M, Pacini L, Bagni C, Kaczmarek L, Dziembowska M (2013) The fragile $x$ mental retardation protein regulates matrix metalloproteinase 9 mRNA at synapses. J Neurosci 33:18234-18241. CrossRef Medline

Kaidanovich-Beilin O, Lipina T, Vukobradovic I, Roder J, Woodgett JR (2011) Assessment of social interaction behaviors. J Vis Exp e2473. CrossRef Medline

Khandjian EW, Tournier B, Séguin S, Tremblay S, De Koninck P, Davidovich L (2009) RNA granules: functions within presynaptic terminals and postsynaptic spines. In: Encyclopedia of neuroscience, Vol 8 (Squire L, Albright T, Bloom F, Gage F, Spitzer N, eds), pp 389-395. New York: Elsevier.

Lauterborn JC, Jafari M, Babayan AH, Gall CM (2013) Environmental enrichment reveals effects of genotype on hippocampal spine morphologies in the mouse model of fragile X syndrome. Cereb Cortex. Advance online publication. Retrieved June 12, 2014. doi:10.1093/cercor/bht249. CrossRef Medline

Lauterborn J, Rex CS, Kramár E, Chen LY, Pandyarajan V, Lynch G, Gall CM (2007) Brain-derived neurotrophic factor rescues synaptic plasticity in a mouse model of fragile X syndrome. J Neurosci 27:10685-10694. CrossRef Medline

Legate KR, Wickström SA, Fässler R (2009) Genetic and cell biological analysis of integrin outside-in signaling. Genes Dev 23:397-418. CrossRef Medline

Leigh MJ, Nguyen DV, Mu Y, Winarni TI, Schneider A, Chechi T, Polussa J, Doucet P, Tassone F, Rivera SM, Hessl D, Hagerman RJ (2013) A randomized double-blind, placebo-controlled trial of minocycline in children and adolescents with fragile X syndrome. J Dev Behav Pediatr 34: 147-155. CrossRef Medline

Levenga J, de Vrij FM, Buijsen RA, Li T, Nieuwenhuizen IM, Pop A, Oostra BA, Willemsen R (2011) Subregion-specific dendritic spine abnormalities in the hippocampus of Fmr1 KO mice. Neurobiol Learn Mem 95:467472. CrossRef Medline

Louhivuori V, Vicario A, Uutela M, Rantamäki T, Louhivuori LM, Castrén E, Tongiorgi E, Akerman KE, Castrén ML (2011) BDNF and TrkB in neuronal differentiation of Fmr1-knockout mouse. Neurobiol Dis 41:469 480. CrossRef Medline

Maddigan A, Truitt L, Arsenault R, Freywald T, Allonby O, Dean J, Naren- 
dran A, Xiang J, Weng A, Napper S, Freywald A (2011) EphB receptors trigger Akt activation and suppress Fas receptor-induced apoptosis in malignant T lymphocytes. J Immunol 187:5983-5994. CrossRef Medline

Manabe S, Gu Z, Lipton SA (2005) Activation of matrix metalloproteinase-9 via neuronal nitric oxide synthase contributes to NMDA-induced retinal ganglion cell death. Invest Ophthalmol Vis Sci 46:4747-4753. CrossRef Medline

Matsuzaki M, Ellis-Davies G, Nemoto T, Miyashita Y, Iino M, Kasai H (2001) Dendritic spine geometry is critical for AMPA receptor expression in hippocampal CA1 pyramidal neurons. Nat Neurosci 4:10861092. CrossRef Medline

Meighan SE, Meighan PC, Choudhury P, Davis CJ, Olson ML, Zornes PA, Wright JW, Harding JW (2006) Effects of extracellular matrix degrading proteases matrix metalloproteinases 3 and 9 on spatial learning and synaptic plasticity. J Neurochem 96:1227-1241. CrossRef Medline

Michalon A, Sidorov M, Ballard TM, Ozmen L, Spooren W, Wettstein JG, Jaeschke G, Bear MF, Lindemann L (2012) Chronic pharmacological mGlu5 inhibition corrects fragile X in adult mice. Neuron 74:49-56. CrossRef Medline

Moeller ML, Shi Y, Reichardt LF, Ethell IM (2006) EphB receptors regulate dendritic spine morphogenesis through the recruitment/phosphorylation of focal adhesion kinase and RhoA activation. J Biol Chem 281:15871598. CrossRef Medline

Nagy V, Bozdagi O, Matynia A, Balcerzyk M, Okulski P, Dzwonek J, Costa RM, Silva AJ, Kaczmarek L, Huntley GW (2006) Matrix metalloproteinase-9 is required for hippocampal late-phase long-term potentiation and memory. J Neurosci 26:1923-1934. CrossRef Medline

Napoli I, Mercaldo V, Boyl PP, Eleuteri B, Zalfa F, De Rubeis S, Di Marino D, Mohr E, Massimi M, Falconi M, Witke W, Costa-Mattioli M, Sonenberg N, Achsel T, Bagni C (2008) The fragile X syndrome protein represses activity-dependent translation through CYFIP1, a new 4E-BP. Cell 134: 1042-1054. CrossRef Medline

Nho RS, Kahm J (2010) Betal-integrin-collagen interaction suppresses FoxO3a by the coordination of Akt and PP2A. J Biol Chem 285:1419514209. CrossRef Medline

Nosyreva ED, Huber KM (2006) Metabotropic receptor-dependent long-term depression persists in the absence of protein synthesis in the mouse model of fragile X syndrome. J Neurophysiol 95:3291-3295. CrossRef Medline

Oostra BA, Willemsen R (2009) Fmr1: a gene with three faces. Biochim Biophys Acta 1790:467-477. CrossRef Medline

Pacey LK, Heximer SP, Hampson DR (2009) Increased GABAB receptormediated signaling reduces the susceptibility of fragile $\mathrm{X}$ knockout mice to audiogenic seizures. Mol Pharmacol 76:18-24. CrossRef Medline

Paribello C, Tao L, Folino A, Berry-Kravis E, Tranfaglia M, Ethell IM, Ethell DW (2010) Open label add-on treatment trial of minocycline in fragile X syndrome. BMC Neurol 10:91-99. CrossRef Medline

Robinson L, Sznajder NA, Riley SC, Anderson RA (2001) Matrix metalloproteinases and tissue inhibitors of metalloproteinases in human fetal testis and ovary. Mol Hum Reprod 7:641-648. CrossRef Medline

Ronesi JA, Huber KM (2008) Homer interactions are necessary for metabotropic glutamate receptor-induced long-term depression and translational activation. J Neurosci 28:543-547. CrossRef Medline

Ronesi JA, Collins KA, Hays SA, Tsai N-P, Guo W, Birnbaum SG, Hu JH, Worley PF, Gibson JR, Huber KM (2012) Disrupted Homer scaffolds mediate abnormal mGluR5 function in a mouse model of fragile X syndrome. Nat Neurosci 15:431-440. CrossRef Medline

Rotschafer SE, Trujillo MS, Dansie LE, Ethell IM, Razak KA (2012) Minocycline treatment reverses ultrasonic vocalization production deficit in a mouse model of fragile X syndrome. Brain Res 1439:7-14. CrossRef Medline

Rudelli RD, Brown WT, Wisniewski K, Jenkins EC, Laure-Kamionowska M, Connell F, Wisniewski HM (1985) Adult fragile X syndrome. Acta Neuropathol 67:289-295. CrossRef Medline

Schneider A, Leigh MJ, Adams P, Nanakul R, Chechi T, Olichney J, Hagerman R, Hessl D (2013) Electrocortical changes associated with minocycline treatment in fragile X syndrome. J Psychopharmacol 27:956-963. CrossRef Medline

Sharma A, Hoeffer CA, Takayasu Y, Miyawaki T, McBride SM, Klann E, Zukin RS (2010) Dysregulation of mTOR signaling in fragile X syndrome. J Neurosci 30:694-702. CrossRef Medline

Shi Y, Ethell IM (2006) Integrins control dendritic spine plasticity in hippocampal neurons through NMDA receptor and Ca2_/calmodulindependent protein kinase II-mediated actin reorganization. J Neurosci 26:1813-1822. CrossRef Medline
Siller SS, Broadie K (2011) Neural circuit architecture defects in a Drosophila model of fragile X syndrome are alleviated by minocycline treatment and genetic removal of matrix metalloproteinase. Dis Model Mech 4:673685. CrossRef Medline

Siu MK, Lee WM, Cheng CY (2003) The interplay of collagen IV, tumor necrosis factor-a, gelatinase B (matrix metalloprotease-9) and tissue inhibitor of metalloproteases- 1 in the basal lamina regulates Sertoli cell tight junction dynamics in the rat testis. Endocrinology 144:371-387. CrossRef Medline

Slegtenhorst-Eegdeman KE, de Rooij DG, Verhoef-Post M, van de Kant HJ, Bakker CE, Oostra BA, Grootegoed JA, Themmen AP (1998) Macroorchidism in FMR1 knockout mice is caused by increased Sertoli cell proliferation during testicular development. Endocrinology 139:156162. Medline

Stefani G, Fraser CE, Darnell JC, Darnell RB (2004) Fragile X mental retardation protein is associated with translating polyribosomes in neuronal cells. J Neurosci 24:7272-7276. CrossRef Medline

Szepesi Z, Bijata M, Ruszczycki B, Kaczmarek L, Wlodarczyk J (2013) Matrix metalloproteinases regulate the formation of dendritic spine head protrusions during chemically induced long-term potentiation. PLoS One 8:e63314. CrossRef Medline

Tashiro A, Yuste R (2003) Structure and molecular organization of dendritic spines. Histol Histopathol 18:617-634. Medline

Udagawa T, Farny NG, Jakovcevski M, Kaphzan H, Alarcon JM, Anilkumar S, Ivshina M, Hurt JA, Nagaoka K, Nalavadi VC, Lorenz LJ, Bassell GJ, Akbarian S, Chattarji S, Klann E, Richter JD (2013) Genetic and acute CPEB1 depletion ameliorate fragile X pathophysiology. Nat Med 19: 1473-1477. CrossRef Medline

Uutela M, Lindholm J, Louhivuori V, Wei H, Louhivuori LM, Pertovaara A, Akerman K, Castrén E, Castrén ML (2012) Reduction of BDNF expression in Fmr1 knockout mice worsens cognitive deficits but improves hyperactivity and sensorimotor deficits. Genes Brain Behav 11:513-523. CrossRef Medline

Verkerk AJ, Pieretti M, Sutcliffe JS, Fu YH, Kuhl DP, Pizzuti A, Reiner O, Richards S, Victoria MF, Zhang FP (1991) Identification of a gene (FMR-1) containing a CGG repeat coincident with a breakpoint cluster region exhibiting length variation in fragile X syndrome. Cell 65:905-914. CrossRef Medline

Wang XB, Bozdagi O, Nikitczuk JS, Zhai ZW, Zhou Q, Huntley GW (2008) Extracellular proteolysis by matrix metalloproteinase- 9 drives dendritic spine enlargement and long-term potentiation coordinately. Proc Natl Acad Sci U S A 105:19520-19525. CrossRef Medline

Weiler IJ, Greenough WT (1999) Synaptic synthesis of the fragile X protein: possible involvement in synapse maturation and elimination. Am J Med Genet 83:248-252. CrossRef Medline

Wlodarczyk J, Mukhina I, Kaczmarek L, Dityatev A (2011) Extracellular matrix molecules, their receptors, and secreted proteases in synaptic plasticity. Dev Neurobiol 71:1040-1053. CrossRef Medline

Yan QJ, Asafo-Adjei PK, Arnold HM, Brown RE, Bauchwitz RP (2004) A phenotypic and molecular characterization of the fmr1-tm1Cgr fragile $X$ mouse. Genes Brain Behav 3:337-359. CrossRef Medline

Yan QJ, Rammal M, Tranfaglia M, Bauchwitz RP (2005) Suppression of two major fragile $\mathrm{X}$ syndrome mouse model phenotypes by the mGluR5 antagonist MPEP. Neuropharmacology 49:1053-1066. CrossRef Medline

Yang F, Je HS, Ji Y, Nagappan G, Hempstead B, Lu B (2009) Pro-BDNFinduced synaptic depression and retraction at developing neuromuscular synapses. J Cell Biol 185:727-741. CrossRef Medline

Yu LN, Zhou XL, Yu J, Huang H, Jiang LS, Zhang FJ, Cao JL, Yan M (2012) PI3K contributed to modulation of spinal nociceptive information related to ephrinBs/EphBs. PLoS One 7:e40930. CrossRef Medline

Zalfa F, Eleuteri B, Dickson KS, Mercaldo V, De Rubeis S, di Penta A, Tabolacci E, Chiurazzi P, Neri G, Grant SG, Bagni C (2007) A new function for the fragile $\mathrm{X}$ mental retardation protein in regulation of PSD-95 mRNA stability. Nat Neurosci 10:578-587. CrossRef Medline

Zhang JW, Gottschall PE (1997) Zymographic measurement of gelatinase activity in brain tissue after detergent extraction and affinity-support purification. J Neurosci Methods 76:15-20. CrossRef Medline

Zhang YQ, Bailey AM, Matthies HJ, Renden RB, Smith MA, Speese SD, Rubin GM, Broadie K (2001) Drosophila fragile X-related gene regulates the MAP1B homolog Futsch to control synaptic structure and function. Cell 107:591-603. CrossRef Medline 